\title{
Source, transport and fate of soil organic matter inferred from microbial biomarker lipids on the East Siberian Arctic Shelf
}

\author{
Juliane Bischoff $^{1, a}$, Robert B. Sparkes ${ }^{2, b}$, Ayça Doğrul Selver ${ }^{2,3}$, Robert G. M. Spencer ${ }^{4}$, Örjan Gustafsson ${ }^{5}$, \\ Igor P. Semiletov ${ }^{6,7,8}$, Oleg V. Dudarev ${ }^{7,8}$, Dirk Wagner ${ }^{9}$, Elizaveta Rivkina ${ }^{10}$, Bart E. van Dongen ${ }^{2}$, and \\ Helen M. Talbot ${ }^{1}$ \\ ${ }^{1}$ School of Civil Engineering and Geosciences, Newcastle University, Newcastle upon Tyne, UK \\ ${ }^{2}$ School of Earth and Environmental Sciences and Williamson Research Centre for Molecular Environmental Science, \\ University of Manchester, Manchester, UK \\ ${ }^{3}$ Balıkesir University, Geological Engineering Department, Balıkesir, Turkey \\ ${ }^{4}$ Earth, Ocean and Atmospheric Science, Florida State University, Tallahassee, FL, USA \\ ${ }^{5}$ Department of Environmental Science and Analytical Chemistry (ACES) and the Bolin Centre for Climate Research, \\ Stockholm University, Stockholm, Sweden \\ ${ }^{6}$ Pacific Oceanological Institute, Far Eastern Branch of the Russian Academy of Sciences, Vladivostok, Russia \\ ${ }^{7}$ International Arctic Research Center, University of Alaska, Fairbanks, USA \\ ${ }^{8}$ National Tomsk Research Polytechnic University, Tomsk, Russia \\ ${ }^{9}$ GFZ German Research Centre for Geosciences, Helmholtz Centre Potsdam, Section 5.3 Geomicrobiology, Telegrafenberg, \\ Potsdam, Germany \\ ${ }^{10}$ Institute of Physicochemical and Biological Problems in Soil Science, Russian Academy of Sciences, Pushchino, Russia \\ ${ }^{a}$ now at: The Lyell Centre, Heriot-Watt University, Edinburgh, UK \\ ${ }^{b}$ now at: School of Science and the Environment, Manchester Metropolitan University, Manchester, UK
}

Correspondence to: J. Bischoff (j.bischoff@ hw.ac.uk) and B. E. van Dongen (bart.vandongen@manchester.ac.uk)

Received: 6 April 2016 - Published in Biogeosciences Discuss.: 15 April 2016

Revised: 8 August 2016 - Accepted: 10 August 2016 - Published: 6 September 2016

\begin{abstract}
The Siberian Arctic contains a globally significant pool of organic carbon (OC) vulnerable to enhanced warming and subsequent release by both fluvial and coastal erosion processes. However, the rate of release, its behaviour in the Arctic Ocean and vulnerability to remineralisation is poorly understood. Here we combine new measurements of microbial biohopanoids including adenosylhopane, a lipid associated with soil microbial communities, with published glycerol dialkyl glycerol tetraethers (GDGTs) and bulk $\delta^{13} \mathrm{C}$ measurements to improve knowledge of the fate of OC transported to the East Siberian Arctic Shelf (ESAS). The microbial hopanoid-based soil OC proxy $R_{\text {soil }}^{\prime}$ ranges from 0.0 to 0.8 across the ESAS, with highest values nearshore and decreases offshore. Across the shelf $R^{\prime}$ soil displays a negative linear correlation with bulk $\delta^{13} \mathrm{C}$ measurements $\left(r^{2}=\right.$ $-0.73, p=<0.001)$. When compared to the GDGT-based OC proxy, the branched and isoprenoid tetraether (BIT) in-
\end{abstract}

dex, a decoupled (non-linear) behaviour on the shelf was observed, particularly in the Buor-Khaya Bay, where the $R^{\prime}$ soil shows limited variation, whereas the BIT index shows a rapid decline moving away from the Lena River outflow channels. This reflects a balance between delivery and removal of OC from different sources. The good correlation between the hopanoid and bulk terrestrial signal suggests a broad range of hopanoid sources, both fluvial and via coastal erosion, whilst GDGTs appear to be primarily sourced via fluvial transport. Analysis of ice complex deposits (ICDs) revealed an average $R^{\prime}$ soil of 0.5 for the Lena Delta, equivalent to that of the Buor-Khaya Bay sediments, whilst ICDs from further east showed higher values $(0.6-0.85)$. Although $R_{\text {soil }}^{\prime}$ correlates more closely with bulk OC than the BIT, our understanding of the endmembers of this system is clearly still incomplete, with variations between the different East Siberian Arctic regions potentially reflecting differences in environmental con- 
ditions (e.g. temperature, $\mathrm{pH}$ ), but other physiological controls on microbial bacteriohopanepolyol (BHP) production under psychrophilic conditions are as yet unknown.

\section{Introduction}

The Arctic permafrost region is a globally significant organic carbon (OC) pool containing approximately $1300 \mathrm{Pg}$ (uncertainty range $\sim 1100$ to $1500 \mathrm{Pg}$ ) of carbon. Approximately $800 \mathrm{Pg}(60 \%)$ is stored below the ground in frozen permafrost, with the remainder $(\sim 500 \mathrm{Pg})$ occurring in nonpermafrost soils, seasonally thawed in the active layer or in deeper taliks (Hugelius et al., 2014). Permafrost is defined as ground (soil or rock and includes ice and organic material) that remains below $0{ }^{\circ} \mathrm{C}$ for at least two consecutive years (van Everdingen, 2005) and is naturally particularly sensitive to an increase in global temperatures. It is therefore a focal point of ongoing climate change research on the observed (e.g. Romanovsky et al., 2010) and predicted rise in atmospheric and soil temperature (IPCC, 2013). Rising temperatures in the Arctic are causing, amongst other severe consequences for society and infrastructure, shifts in hydrological processes and progressive deepening and duration of permafrost thawing during the Arctic summer (Vonk et al., 2015). This destabilisation of permafrost deposits will increase the re-distribution of terrestrial organic matter (OM) to the Arctic Shelf and ultimately the Arctic Ocean by (1) transportation via the major Arctic rivers and (2) erosion of coastal areas.

The Arctic Ocean receives around $10 \%$ of the global river discharge, while representing only $1 \%$ of the global ocean water body (Opsahl et al., 1999). Climate change has already increased the water discharge to the Arctic Ocean (Peterson et al., 2002; Rawlins et al., 2010). Arctic rivers are distinct in their hydrologic regime with pronounced seasonality (Holmes et al., 2012, 2013). They discharge the majority of their annual load of water, sediment and total OC from May to July (Dittmar and Kattner, 2003; Holmes et al., 2012, 2013). The drainage basins of these rivers include areas of continuous and discontinuous permafrost (Feng et al., 2015; Gustafsson et al., 2011; Kotlyakov and Khromova, 2002; and references therein). Thawing of permafrost deposits is linked to a destabilisation of stored carbon by top-down thawing at the activelayer-permafrost interface leading to collapse of ice-rich permafrost, also known as thermokarst, resulting in hydrological changes (Vonk et al., 2015). Thermokarst processes including massive erosional events can lead to increased mobility of old carbon (both dissolved and particulate) from the lower layers and strongly affects the balance of carbon dioxide $\left(\mathrm{CO}_{2}\right)$ and methane $\left(\mathrm{CH}_{4}\right)$ emissions from these environments (e.g. Gustafsson et al., 2011; Schuur et al., 2009; Vonk et al., 2015). For example, between 1985 and 2004 an increase in the proportion of mobilised terrestrial OC accounted for by ancient carbon of 3-6\% has been estimated (Feng et al., 2013). Not only will this increased transport of older material increase the release of $\mathrm{CO}_{2}$ to the atmosphere (Drake et al., 2015; Mann et al., 2015; Spencer et al., 2015) but already observed increases in river discharge will also lead to increased terrestrial OC input into the Arctic Ocean (Savelieva et al., 2000; Semiletov et al., 2000, 2013). However, the fate of this terrestrial OC in the Arctic Ocean system is not well understood.

Additionally, OC is stored, frozen, within coastal ice complex deposits (ICDs) - this can also be a major source of terrestrial OC to the Arctic Ocean (Lantuit et al., 2013). These deposits erode at a rate greater than that of temperate coasts with an average rate for the Arctic coast of $0.5 \mathrm{~m} \mathrm{yr}^{-1}$, albeit with high local variability, up to $10 \mathrm{~m} \mathrm{yr}^{-1}$ (Lantuit et al., 2013). The highest rates are found in the Laptev, East Siberian and Beaufort seas, where the majority of the coast comprises frozen unlithified material highly susceptible to erosion (Fig. 1; Lantuit et al., 2012, 2013). Although at present much of the unlithified coast is located in areas still largely protected by sea ice, continuing decline in sea ice extent will expose this material to erosion and increase sediment flux to the ocean (Lantuit et al., 2013). The relative contribution of permafrost ICD erosion to sedimentary carbon in the East Siberian Arctic Sea (ESAS) is estimated to be $57 \pm 1.6 \%$ (Vonk et al., 2012). Other recent estimates vary widely but suggest that between 15 and $66 \%$ of this carbon is remineralised to $\mathrm{CO}_{2}$ acting as a positive feedback for climate warming, whilst the remainder is buried in shelf sediments (Knoblauch et al., 2013; Vonk et al., 2012). Furthermore, Tesi et al. (2016) showed that the potential for burial and degradation of terrestrial OC on the ESAS, based on the different chemical reactivity of different components, is dependent on the source material (topsoil vs. ICD) and the transportation pathways (river run-off vs. coastal erosion), highlighting the need to better understand these sources.

A number of methods are used to trace different primary sources of sedimentary $\mathrm{OM}$ on the Arctic shelves including bulk $\delta^{13} \mathrm{C}, \delta^{15} \mathrm{~N}$ and $\mathrm{C} / \mathrm{N}$, as well as molecular ratios (Cooke et al., 2009; Drenzek et al., 2007; Feng et al., 2013, 2015; Goñi et al., 2005; Guo et al., 2004; Gustafsson et al., 2011; Semiletov, 1999a, b; Tesi et al., 2014; van Dongen et al., 2008; Vonk et al., 2012). The molecular ratios include the branched and isoprenoid tetraether (BIT) index (Hopmans et al., 2004), based on comparison of branched glycerol dialkyl glycerol tetraethers (brGDGTs) from terrestrial soil environments and the marine isoprenoid GDGT crenarchaeol (e.g. De Jonge et al., 2014, 2015; Doğrul Selver et al., 2015; Sparkes et al., 2015), and the bacteriohopanepolyol (BHP)based $R_{\text {soil }}^{\prime}$ index (De Jonge et al., 2016; Doğrul Selver et al., 2012, 2015).

BHPs are microbial membrane lipids comprising pentacyclic triterpenoids with an extended polyfunctionalised side chain (Rohmer, 1993; see Table S1 for structures). They oc- 


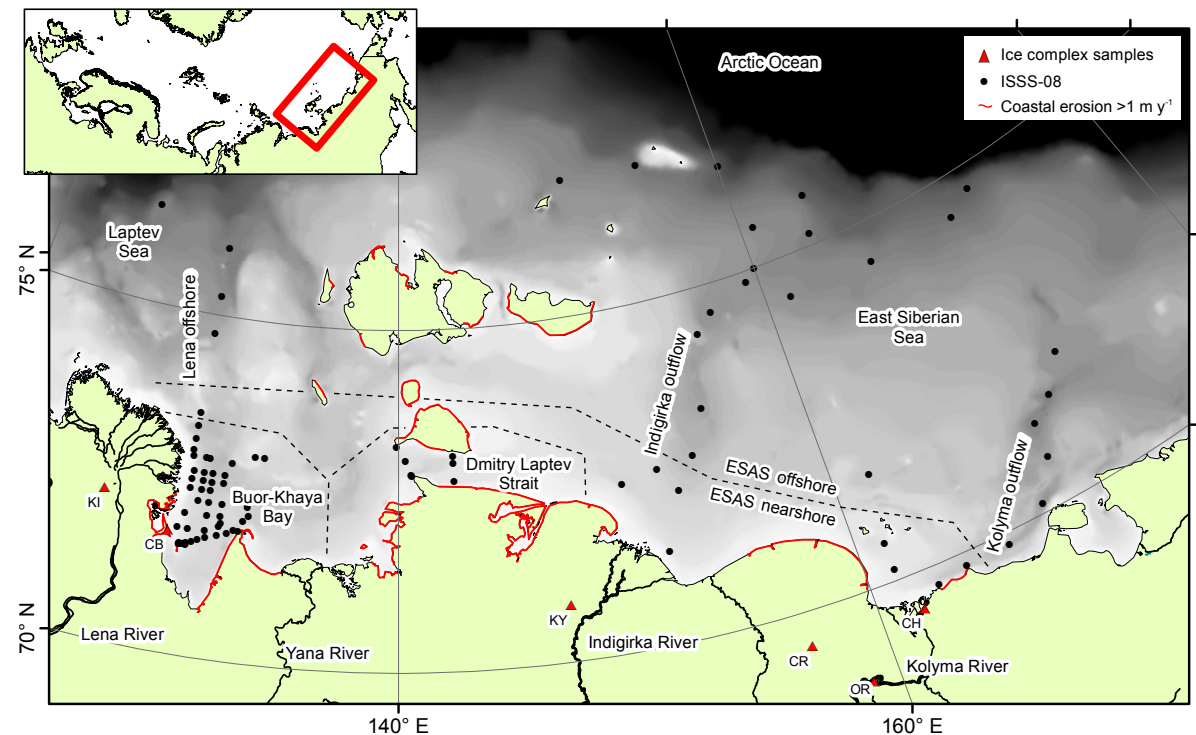

Figure 1. Map of the East Siberian Arctic Shelf (ESAS) showing sampling stations of the International Siberian Shelf Studies 2008 (ISSS-08) expedition and location of Ice complex deposit (ICD) samples investigated in this study. Key regions discussed in the text are highlighted. Lower courses and outflows of four great Russian Arctic rivers are labelled. Section of coastline indicated in red are areas of moderate to high rates of coastal erosion ( $>1 \mathrm{~m} \mathrm{yr}^{-1}$ ) as defined by Lantuit et al. (2011). Key: KI, Kurungnakh Island; CB, Cape Bykovsky; KY, Indigirka (Tesi et al., 2014); CR, Chukochya River; OR, Omolon River; CH, Cherskii (Tesi et al., 2014).

cur in varying concentrations and compositions in a range of environmental settings such as Arctic permafrost soils (Höfle et al., 2015; Rethemeyer et al., 2010), lakes (Coolen et al., 2008; Talbot and Farrimond, 2007; Talbot et al., 2003c), and marine sediments (e.g. Blumenberg et al., 2009, 2010, 2013; Cooke et al., 2009; Doğrul Selver et al., 2012; Talbot et al., 2014; Wagner et al., 2014; Zhu et al., 2011). Recent studies have indicated the potential of a specific group of BHPs with a cyclised side chain to be used as a tracer for soil organic matter (SOM) input in aquatic settings. Adenosylhopane (1a; see Table S1 for structures; Bradley et al., 2010, and references therein), two related structures with yet undetermined terminal groups termed "adenosylhopane type 2" (1) ; Cooke et al., 2008a) and "adenosylhopane type 3" (1b'; Rethemeyer et al., 2010) together with their C-2 methylated homologues (2a, $\mathbf{2 b}$ and 2b', respectively) are common compounds in soils (Cooke et al., 2008a; Kim et al., 2011; Rethemeyer et al., 2010; Spencer-Jones et al., 2015; Xu et al., 2009; Zhu et al., 2011). However, these compounds are rarely found in marine settings with the exception of deep-sea fan systems, which comprise a significant proportion of terrestrial OM including BHPs (Cooke et al., 2008b; Handley et al., 2010; Wagner et al., 2014). A BHP-based SOM proxy, the $R_{\text {soil }}$ index, was proposed in which the relative proportion of soil marker BHPs (adenosylhopane and related compounds) to the combined total of soil markers plus the commonly occurring BHP bacteriohopane-32,33,34,35-tetrol (BHT, 1f) is calculated (Zhu et al., 2011). The use of BHT in this context is complicated as it is also found in varying proportions in soils but is frequently the most significant and, in some cases, only BHP in marine sediments, hence its proposal as the only possible representative compound for marine OM-dominated sediments (De Jonge et al., 2016; Zhu et al., 2011).

The $R_{\text {soil }}$ index has been investigated in various settings, including the Yangtze River-East China Sea surface sediment transect (Zhu et al., 2011) and several (sub-)Arctic land to ocean transects (De Jonge et al., 2016; Doğrul Selver et al., 2012, 2015). These studies showed that it can be used to trace SOM exported from land to ocean. However, due to the limited and intermittent occurrence of methylated compounds in the sub-Arctic setting, $R_{\text {soil }}$ (Eq. 1) was modified to $R^{\prime}$ soil for application in Arctic settings where the C-2 methylated soil markers are scarce and therefore were excluded (Eq. 2; Doğrul Selver et al., 2012, 2015).

$$
R_{\text {soil }}=\frac{\text { soil BHPs }\left(\mathbf{1 a}+\mathbf{1} \mathbf{b}+\mathbf{1} \mathbf{b}^{\prime}+\mathbf{2} \mathbf{a}+\mathbf{2} \mathbf{b}+\mathbf{2} \mathbf{b}^{\prime}\right)}{\text { soil BHPs }\left(\mathbf{1 a}+\mathbf{1 b}+\mathbf{1} \mathbf{b}^{\prime}+\mathbf{2} \mathbf{a}+\mathbf{2} \mathbf{b}+\mathbf{2} \mathbf{b}^{\prime}\right)+\text { BHT }(\mathbf{1 f})}
$$

$R^{\prime}{ }_{\text {soil }}=\frac{\text { soil BHPs }\left(\mathbf{1} \mathbf{a}+\mathbf{1 b}+\mathbf{1} \mathbf{b}^{\prime}\right)}{\operatorname{soil~BHPs}\left(\mathbf{1} \mathbf{a}+\mathbf{1 b}+\mathbf{1} \mathbf{b}^{\prime}\right)+\operatorname{BHT}(\mathbf{1 f})}$

This study focuses on the ESAS, a region dominated by fluvial input from three major rivers, namely the Lena, Indigirka and Kolyma (Gordeev, 2006), as well as a site of significant erosion of coastal ICD (Fig. 1; Lantuit et al., 2012). Recently, Sparkes et al. (2015) used the GDGT-based BIT proxy to trace terrestrial OM on the ESAS shelf using the same sediment samples and found a decoupling between BIT and bulk $\delta^{13} \mathrm{C}$, suggesting that GDGTs were (primarily) sourced 
via riverine transport and not from erosion of coastal ICD. In addition, a strong linear correlation between bulk $\delta^{13} \mathrm{C}$ and $R_{\text {soil }}^{\prime}$ and a strong but non-linear relationship between the BIT index and $R^{\prime}$ soil was observed by Doğrul Selver et al. (2015) in surface sediments along the offshore transect off the Kolyma River. This suggests a decoupling between these microbial-based biomarker proxies and different and/or additional sources of BHPs to the ESAS compared to the GDGTs. Erosion of ICD was proposed as a likely source for the BHPs, suggesting that these biomarker proxies probably reflect different OC sources (Doğrul Selver et al., 2015). It has, however, been suggested that coastal cliffs could also be a source of branched GDGTs, at least in sites without major river inputs (De Jonge et al., 2015). At this time, it remains unclear (i) whether the decoupling between these bacterial biomarker-based proxies is unique to the Kolyma region or more widely applicable to the whole ESAS and (ii) whether the soil marker BHP pool has a mixed input from ICD and river-transported OC or can be used as a proxy for ICD.

Therefore, this study investigates the abundance and composition of terrestrial microbial (soil marker) BHPs across the land-ocean transect of the ESAS in conjunction with the recently published BIT data obtained at the same sites (Sparkes et al., 2015). This study includes new data on BHPs in ICD from the Lena Delta and Indigirka and Kolyma riverbanks in order to further constrain the source of OC transported to and deposited into the Arctic Ocean.

\section{Materials and methods}

\subsection{Study area and sample collection}

This study focuses on the ESAS with sediment samples from the Laptev Sea, Buor-Khaya Bay, Dmitry Laptev Strait and East Siberian Sea (Fig. 1). Comprehensive fieldwork was conducted in August-September 2008 as part of the International Siberian Shelf Studies 2008 expedition (ISSS 08; Semiletov and Gustafsson, 2009). Surface sediments were recovered using a dual gravity corer or a van Veen grab sampler from H/V Yakob Smirnitskyi (ESAS) and TB-0012 (Buor-Khaya Bay). The sediment samples were transferred with stainless steel spatulas to polyethylene containers and frozen at $-18^{\circ} \mathrm{C}$ for transport and storage (Karlsson et al., 2011). Subsamples were taken and freeze-dried for subsequent total lipid extraction (Sparkes et al., 2015).

The sediments investigated in this study were grouped based on their location on the ESAS (Fig. 1; Table S2; Sparkes et al., 2015). Samples were grouped longitudinally, into the Buor-Khaya Bay and associated region offshore of the Lena River delta (the Laptev Sea), the Dmitry Laptev Strait (the narrow channel between the coastline at $\sim 140^{\circ} \mathrm{E}$ and the New Siberian Islands, splitting the ESAS up into two distinct areas - the Laptev Sea and the East Siberian Sea), the region offshore of the Indigirka River mouth and the re- gion offshore of the Kolyma River mouth. The Indigirka and Kolyma River mouth offshore regions are generally equivalent to the western and eastern East Siberian Sea regions, respectively, as identified by Semiletov et al. (2005). The ESAS samples have also been classified latitudinally, into the nearshore ESAS ( $<150 \mathrm{~km}$ from river outflows) and offshore ESAS ( $>150 \mathrm{~km}$ from river outflows).

In addition to surface sediment samples throughout the ESAS, this study also includes ICD samples from locations on the Siberian mainland, including the central Lena Delta, Cape Bykovsky, and the Kolyma and Indigirka river banks. The site on Kurungnakh Island (central Lena Delta; $72^{\circ} 20^{\prime} \mathrm{N}, 126^{\circ} 17^{\prime} \mathrm{E}$ ) was drilled during the Russian-German LENA 2002 expedition in July 2002 (Bischoff et al., 2013) and a $24 \mathrm{~m}$ long permafrost core from a low-centred icewedge polygon was recovered (Grigoriev, 2003). In total 23 samples from depths 0.34 to $24.55 \mathrm{~m}$ (Table S3) were chosen for BHP analysis. An additional ice complex sample (CB IC 1.9; Table S3) was obtained from Cape Bykovsky. The Bykovsky Peninsula is located in the vicinity of the Lena Delta in an area of significant coastal erosion (Lantuit et al., 2011). Ice complex samples from the Kolyma region were obtained from the Chukochya River (CR; Fig. 1), which outflows in the Kolyma Gulf; the Omolon River (OR; Fig. 1), a tributary of the Kolyma River; and from Cherskii $(\mathrm{CH}$, Fig. 1; Table S3; Tesi et al., 2014). An additional profile from the Indigirka watershed is also included for comparison (KY, Fig. 1; Tesi et al., 2014).

\subsection{Bulk analysis}

Data for the ISSS-08 sediments are taken from Karlsson et al. (2011, see Table S2). Total organic carbon (TOC) data for the Indigirka and Cherskii profiles are taken from Tesi et al. (2014) (see Table S3). The Cape Bykovsky, Chukochya River and Omolon River permafrost ICD samples were prepared for carbon isotope analysis according to Harris et al. (2001) and analysed at the University of California, Davis, Stable Isotope Facility.

\subsection{Extraction of ESAS sediment samples}

Sediment samples were extracted using a modified BlighDyer method as described in more detail in Doğrul Selver et al. (2015) and Sparkes et al. (2015). Briefly, sediment $(5 \mathrm{~g})$ was ultrasonically extracted using a monophasic mixture of methanol/dichloromethane/phosphate buffer $(0.05 \mathrm{M}$, pH 7.4; $2: 1: 0.8 v: v: v$ ). The supernatant was separated by centrifugation and the remaining sediments re-extracted twice. The combined organic phases were evaporated to dryness. After extraction, the total lipid extracts (TLEs) were re-dissolved in dichloromethane/methanol $(2: 1)$ and separated into fractions with one-sixth of the TLE used for BHP analysis. 


\subsection{Extraction of ice complex samples}

Freeze-dried and ground ICD samples were extracted using a modified Bligh-Dyer method (1959) that was adapted from the method described in Cooke et al. (2008a). Briefly, samples $(\sim 3 \mathrm{~g}$, dry weight $)$ were ultrasonically extracted with a monophasic mixture of methanol/chloroform/water $(10: 5: 4 v: v: v)$. Deviating from the method described in Cooke et al. (2008a), the sonication steps were reduced to 30 min at $40^{\circ} \mathrm{C}$ without the subsequent overnight shaking. The supernatant was removed after centrifugation $(16000 \mathrm{~g}$, $10 \mathrm{~min}$ ) and the remaining sediment was re-extracted twice. After phase separation via addition of water $(5 \mathrm{~mL})$ and chloroform $(5 \mathrm{~mL})$, the organic phases were combined, evaporated to dryness, and blown to dryness under $\mathrm{N}_{2}$. Extracts were then re-dissolved in $2: 1$ chloroform/methanol and onethird of the TLE was used for BHP analyses.

\subsection{Solid phase extraction and derivatisation of BHPs}

Aliquots (one-sixth for sediments and one-third for terrestrial materials) of the TLE were loaded onto $\mathrm{NH}_{2}$ solid phase extraction (SPE) cartridges pre-conditioned with $6 \mathrm{~mL}$ of hexane $(1 \mathrm{~g} / 6 \mathrm{~mL}$; Isolute, Biotage, Sweden), in $200 \mu \mathrm{L}$ chloroform and separated into two fractions (Fr): Fr. 1 (nonpolar + acidic, $6 \mathrm{~mL}$ of diethylether/acetic acid $(98: 2, v: v))$ and Fr. 2 (polar, $12 \mathrm{~mL}$ of methanol), which contained all BHPs except 32,35-anhydroBHT (e.g. Bednarczyk et al., 2005). After separation, the internal standard ( $5 \alpha$-pregnane$3 \beta, 20 \beta$-diol) was added to Fr. 2 and dried under $\mathrm{N}_{2}$. This SPE method was adapted from a method commonly used in other studies of complex polar lipids from environmental samples (e.g. Lupascu et al., 2014). Fr. 2 was acetylated with pyridine/acetic anhydride $(1: 1, v: v ; 500 \mu \mathrm{L})$ for $1 \mathrm{~h}$ at $50^{\circ} \mathrm{C}$ and left at room temperature overnight. The samples were evaporated to dryness, re-dissolved in methanol/propan-2-ol $(60: 40, v: v)$ and filtered through a $0.2 \mu \mathrm{m}$ PTFE syringe filter. For BHP analysis, the samples were dissolved in methanol/propan-2-ol $(60: 40, v: v$; $500 \mu \mathrm{L})$. Sample injection volume was $10 \mu \mathrm{L}$.

\subsection{Analytical HPLC-APCI-MS}

BHPs were identified and measured using reverse-phase HPLC-APCI-MS as previously described in Cooke et al. (2008a). Chromatographic separation was achieved under the conditions described in van Winden et al. (2012b). BHP structures were identified based on previously published spectra (Cooke et al., 2008a; Rethemeyer et al., 2010; Talbot and Farrimond, 2007; Talbot et al., 2003a, b). Semiquantitative estimation of BHP concentrations was achieved by employing the characteristic base peak ion areas of individual BHPs in mass chromatograms (from SCAN 1) relative to the $m / z 345$ chromatogram base peak area of the acetylated $5 \alpha$-pregnane-3 $\beta, 20 \beta$-diol internal standard. Averaged relative response factors relative to the internal standard, determined from a suite of acetylated BHP standards, were used to adjust the BHP peak areas where $\mathrm{N}$-containing compounds give an average response 12 times that of the standard and compounds without $\mathrm{N} 8$ times that of the standard (for further details see van Winden et al., 2012b). The reproducibility of triplicate injections was 3-6\% RSD (standard error: $\pm 1-4 \mu \mathrm{g} \mathrm{g}_{\mathrm{OC}}^{-1}$ ) for BHT and 5-8 \% RSD (standard error: $\pm 1-$ $2 \mu \mathrm{g} \mathrm{g}_{\mathrm{OC}}^{-1}$ ) for adenosylhopane in the environmental samples, resulting in an absolute standard error of on average \pm 0.01 for $R^{\prime}$ soil (see Sect. 1, Eq. 2).

\section{Results and discussion}

OC concentrations and bulk carbon isotopes for sediments recovered throughout the ISSS-08 expedition have been reported previously (Vonk et al., 2012; Karlsson et al., 2011). OC concentrations ranged from 0.68 to $2.25 \mathrm{wt}$ \% $\mathrm{C}$ and were highest in Buor-Khaya Bay, with values for the different regions shown in Table S2 (see also Sparkes et al., 2015). Bulk $\delta^{13} \mathrm{C}$ values ranged from -21.2 to $-27.4 \%$ with most depleted values reported in sediments in Dmitry Laptev Strait and ESAS nearshore sediments.

\subsection{BHP concentrations and distributions in ESAS surface sediments}

In total, 92 surface sediment samples throughout the ESAS in Buor-Khaya Bay, Dmitry Laptev Strait, and Kolyma River and Indigirka River mouth transects were analysed for their BHP composition (Table S2). Up to 16 individual BHPs were identified in the ESAS sediments, with the total concentration of BHPs ranging from 12 to $824 \mu \mathrm{gg}_{\mathrm{OC}}^{-1}$ (Table S2). However, their concentrations and distributions differed with distance to the mainland throughout the shelf. BHT (1f) was the most abundant single BHP, ranging from 9 to $313 \mu \mathrm{g} \mathrm{g}-1$ (Table S1, Figs. 2a and 3a). The relative proportion of BHT was lowest in Buor-Khaya Bay sediments close to the mainland (mean $=37 \%$ of all detected BHPs) rising to $80 \%$ (mean $=65 \%)$ of all detected BHPs in the ESAS offshore sediments furthest away from the mainland. Highest BHT concentrations were measured closest to the mainland except in the region of the Indigirka outflow (samples YS26 to 30; Table S2), where values were lower than in all other nearshore settings (Fig. 2a). However, mean concentrations were stable with increasing distance from the mainland (Fig. 3a) and considerable amounts of BHT (up to $77 \mu \mathrm{g} \mathrm{g}_{\mathrm{OC}}^{-1}$ ) are still detectable at $293 \mathrm{~km}$ offshore.

In addition to the ubiquitous and abundant BHT (1f), a suite of other polyhydroxylated BHPs related to BHT were detected, including the BHT isomer (1f'), which has been linked to production by pelagic anaerobic organisms performing anaerobic ammonium oxidation (annamox; Rush et al., 2014). The C-2 methylated homologue 2- 

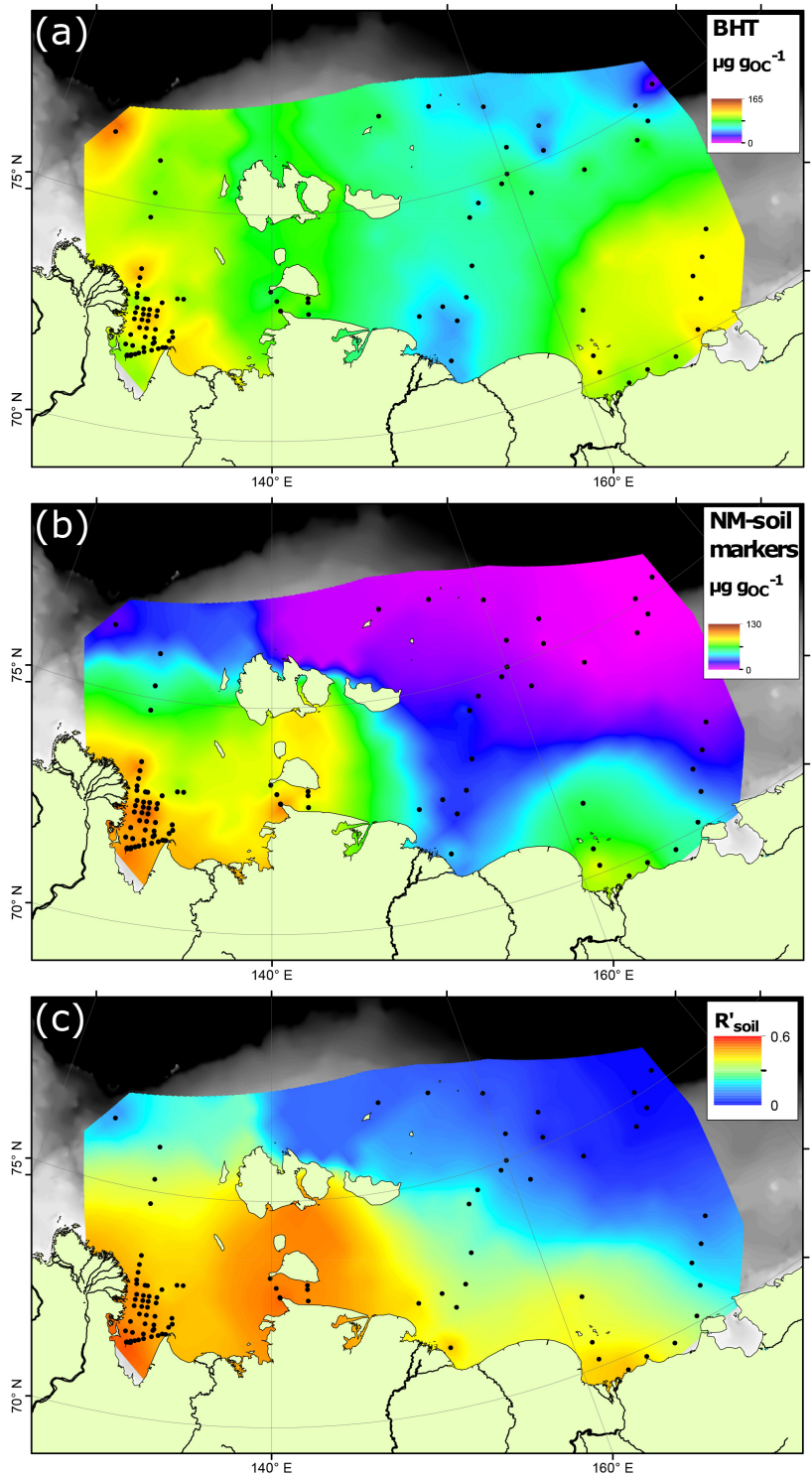

Figure 2. Maps of (a) BHT and (b) summed non-methylated soil marker concentrations $\left(\mu \mathrm{gg}_{\mathrm{OC}}^{-1}\right)$ and (c) the resulting $R^{\prime}$ soil in ISSS sediments from the ESAS. Maps were interpolated using a kriging algorithm (ArcGIS v.10; ESRI Ltd) and the locations of the ISSS-08 stations are shown as black dots.

MeBHT (2f), unsaturated BHT ( $\left.\Delta^{6}-\mathbf{1 f}\right)$ and bacteriohopane30,31,32,33,34,35-hexol (1g) were also common, especially in Buor-Khaya Bay, although at much lower concentration than BHT (Table S2). Soil marker BHPs identified included high proportions of adenosylhopane (1a), followed by adenosylhopane type 2 (1) and adenosylhopane type 3 (1)'). The soil marker type 2 and 3 compounds are related to adenosylhopane but have different and as yet uncharacterised terminal groups compared to adenosylhopane as identified by LC$\mathrm{MS}^{n}$ (Table S1; Rethemeyer et al., 2010). The C-2 methylated soil markers (2a, 2b, 2b'; Table S1) were present inter-
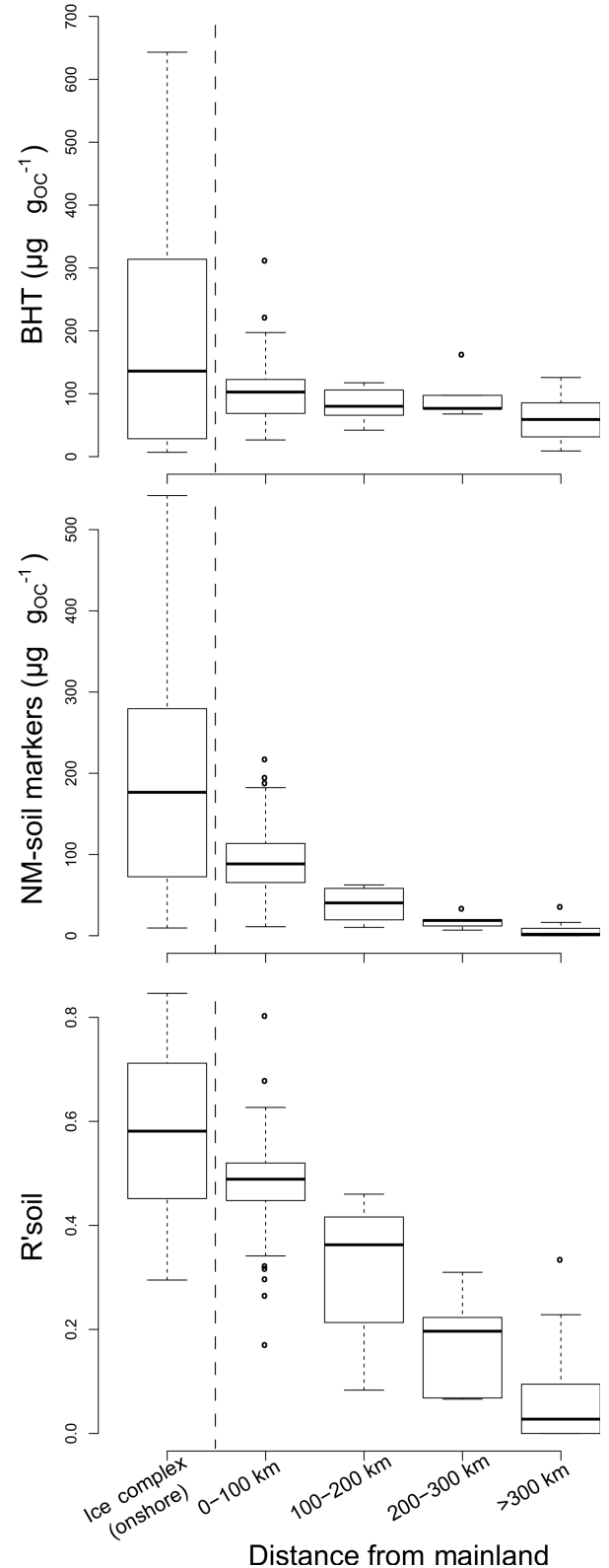

Figure 3. Box plots summarising the concentrations of (a) BHT, (b) summed non-methylated soil markers and (c) the resulting $R^{\prime}$ soil on the ESAS, grouped by distance from river mouths. Concentrations in ice complex samples are also shown (see Fig. 1 for locations). Thick lines show the median values, boxes the 25 th and 75 th percentiles, whiskers the maximum and minimum values within 1.5 times the interquartile range, and circular symbols outliers beyond this threshold.

mittently and always at lower concentration than the corresponding non-methylated structures. Generally, the concentrations of all non-methylated soil markers are highest in samples closer to the coast $(0-100 \mathrm{~km})$ and decrease with distance from the river outflows (Figs. 2b and 3b; Table S2) showing similar trends. 
Sediments of Buor-Khaya Bay and Dmitry Laptev Strait were characterised by high amounts of adenosylhopane, with a mean average of $64 \mu \mathrm{g} \mathrm{g}_{\text {OC }}^{-1}$ (range $7-137 \mu \mathrm{gg}_{\mathrm{OC}}^{-1}$; Table S2) and total non-methylated soil markers accounted for up to $66 \%$ of total BHPs although the mean proportion was lower at $36 \%$. Sediments collected from the ESAS offshore region contain noticeably lower soil marker BHPs both in absolute and relative concentrations with non-methylated soil markers ranging from 0 to $62 \mu \mathrm{gg}_{\mathrm{OC}}^{-1}$ (mean $11 \%$ of all detected BHPs; Table S2; Figs. 2b and 3b). Methylated compounds were frequently below the detection limit (Table S2) as previously reported in Arctic and sub-Arctic River mouth surface sediment transects (Doğrul Selver et al., 2012, 2015).

Total concentrations of non-methylated soil markers in ESAS sediments with a range of $0-218 \mu \mathrm{gg}_{\mathrm{OC}}^{-1}$ are similar to sediments from the Yenisei River system, including the Yenisei River mouth, gulf, outflow and nearby Kara Sea (9$508 \mu \mathrm{gg}_{\mathrm{OC}}^{-1}$; De Jonge et al., 2016). The highest values occurred in the Yenisei River mouth sediments and also in Khalmyer Bay (329-435 $\mu \mathrm{gg}_{\mathrm{OC}}^{-1}$ ), a nearby area of coastal erosion, although not directly drained by the Yenisei River itself. However, in the Yenisei mouth, Khalmyer Bay, BuorKhaya Bay and Dmitry Laptev Strait, non-methylated soil markers had very similar mean relative abundance as a proportion of total BHPs of 30-40\%. This reflects a significant contribution of these terrestrial compounds to the total BHP assemblage in Arctic settings (see also Cooke et al., 2009; Taylor and Harvey, 2011) and indicates a strong terrestrial signal in the Arctic Shelf sediments. The proportion of total soil markers in sediments from the outflow of other nonArctic rivers has been shown to be somewhat lower (e.g. $<20 \%$ from the estuary and seaward of the Yangtze River, Zhu et al., 2011; < $8 \%$ Congo River estuary, Spencer-Jones et al., 2015), thus emphasising the importance of obtaining values for local endmembers. The higher abundance of these highly functionalised compounds in Arctic sediments may be a result of better preservation under the cold-temperature conditions of this region. Additionally, temperature may also influence the microbiological community, leading to deliberate accumulation of adenosylhopane and/or limited biosynthetic transformation of the BHP precursor in this extreme environment (see Rethemeyer et al., 2010).

Other BHPs identified include three structures with amine functional groups at the $\mathrm{C}-35$ position. The concentration of aminotriol (1e; Table S1) varied from 0 to $53 \mu \mathrm{g} \mathrm{g}_{\mathrm{OC}}^{-1}$ (mean $6.4 \%$ of all analysed BHPs) throughout the ESAS (Table S2). Aminotetrol (1d) was generally less abundant across the ESAS (0-13 $\left.\mu \mathrm{g} \mathrm{g}_{\mathrm{OC}}^{-1}\right)$ and aminopentol (1c) was identified in 37 of the 47 Buor-Khaya Bay sediments and only occasionally in other areas (Table S2). Aminotetrol and aminopentol in particular have been linked to aerobic methane oxidising bacterial sources and have been proposed as markers for terrestrial methane oxidation in continental wetlands, which is then subsequently recorded in marine (e.g. deepsea fan) sediments from the Republic of Congo (Spencer-
Jones et al., 2015; Talbot et al., 2014; Wagner et al., 2014). More recently, De Jonge et al. (2016) identified aminopentol in sediments of the Yenisei River outflow and tentatively proposed that it might indicate decomposition of sub-sea permafrost with associated methane release and subsequent microbial oxidation. Here in Buor-Khaya Bay, concentrations of aminopentol (1c) ranged from 0 to $9.5 \mu \mathrm{g} \mathrm{g}_{\mathrm{OC}}^{-1}$, considerably lower than values reported in De Jonge et al. (2016, $\left.0-48 \mu \mathrm{gg}_{\mathrm{OC}}^{-1}\right)$. It is therefore possible that the aminopentol signature is fluvially transported from areas of active aerobic methane oxidation within the catchment (i.e. polygonal tundra, wetlands, thermokarst lakes) or, alternatively, indicates oxidation of methane released from sub-sea permafrost deposits known to be common across the ESAS including Buor-Khaya Bay (Shakhova and Semiletov, 2007; Shakhova et al., 2009, 2010a, b, 2014, 2015).

The ESAS surface sediments generally had only low levels of composite BHPs (i.e. BHPs with more complex moiety at the C-35 position such as a sugar or amino-sugar; e.g. Rohmer, 1993). The only exceptions were BHT cyclitol ether $(\mathbf{1 h})$, which was found in concentrations ranging from 0 to $49 \mu \mathrm{gg}_{\mathrm{OC}}^{-1}$, with a mean of $7.7 \mu \mathrm{gg}_{\mathrm{OC}}^{-1}(0-10 \%$ of all analysed BHPs), and BHT glucosamine (1i), which was even less common (Table S2). Both of these structures have a wide range of known sources, so they cannot be assigned to any specific group of source organisms (see review in Talbot et al., 2008).

\section{2 $R_{\text {soil, }}^{\prime}$, stable carbon isotopes and BIT in ESAS sediments}

Bulk carbon isotope values $\left(\delta^{13} \mathrm{C}\right)$ are commonly used as a proxy for marine vs. terrestrial influence on sedimentary OC composition as terrestrial plants using the C3 synthesis pathway typically have more depleted values than $\mathrm{OC}$ produced via marine primary productivity (Hayes, 1993; Meyers, 1997; van Dongen et al., 2008). Here, we compared bulk carbon isotopes to the BHP-based $R_{\text {soil }}^{\prime}$ proxy

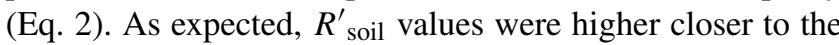
coast and reduced gradually with increasing distance offshore (Figs. 2c, 3c), including the region off the Indigirka which had somewhat lower absolute concentrations of the individual BHPs compared to the more eastern and western extents of the ESAS region (Fig. 2a, b). The highest values occurred in Buor-Khaya Bay (maximum $R_{\text {soil }}^{\prime}=0.80$; Table S2); however, the mean values for Buor-Khaya Bay and Dmitry Laptev Strait sediments were very similar at 0.49 and 0.52, respectively (Fig. 4). The ESAS nearshore sediments had an average only slightly lower at 0.41 , whilst the average for the offshore sediments was 0.14 (range 0.42 to 0.00 ; Fig. 4, Table S2).

A clear negative linear relationship was observed between $R^{\prime}$ soil and bulk $\delta^{13} \mathrm{C}\left(r^{2}=-0.73, p<0.001\right.$; Fig. 5a) across the ESAS in agreement with a pilot study of soil microbial biomarkers in ESAS surface sediments from the Kolyma 


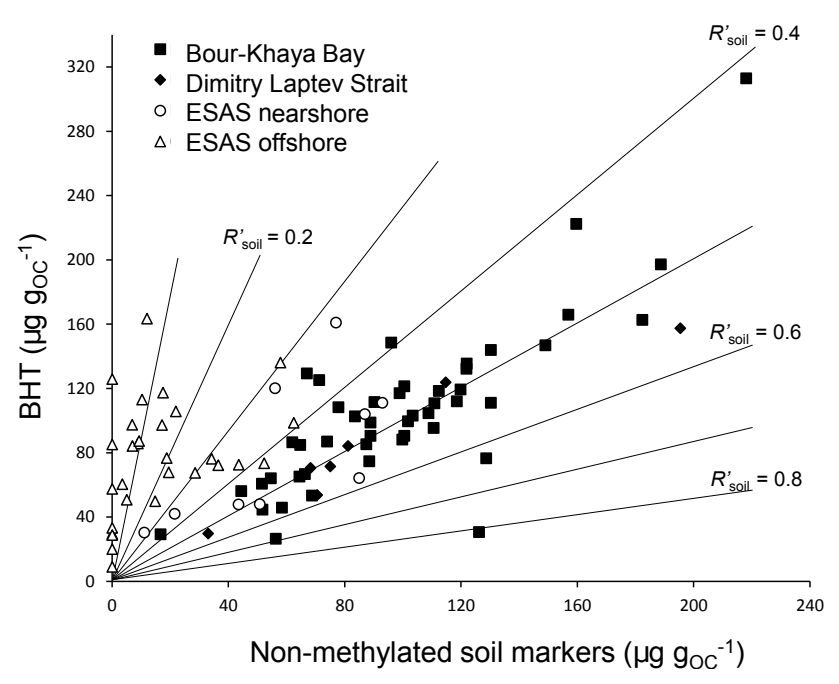

Figure 4. Plot of the concentrations $\left(\mu \mathrm{gg}_{\mathrm{OC}}^{-1}\right)$ of BHT vs. nonmethylated soil markers grouped according to sampling location in Buor-Khaya Bay, Dmitry Laptev Strait, ESAS nearshore and offshore. Labelled contours show the $R^{\prime}$ soil index values.

River mouth offshore transect where strong linear correlations were observed between the $R^{\prime}$ soil proxy and distance from river mouth $\left(r^{2}=0.97\right)$ and bulk $\delta^{13} \mathrm{C}\left(r^{2}=0.96\right.$; Doğrul Selver et al., 2015). Although bulk $\delta^{13} \mathrm{C}$ in ESAS surface sediments did display a linear relationship with distance offshore (Vonk et al., 2012), previous comparison of bulk $\delta^{13} \mathrm{C}$ and BIT values from the ESAS surface sediments displayed a strongly non-linear correlation (Fig. 5c; Sparkes et al., 2015). This was shown to result from a rapid reduction in concentration of brGDGTs in near-coastal sediments $(<150 \mathrm{~km}$ from shoreline), causing a drop in BIT values from $\sim 1$ to $\sim 0.25$ with little variation in bulk $\delta^{13} \mathrm{C}$ followed by an enrichment in bulk carbon isotopes towards more marine values concomitant with a slower decline in BIT values towards 0 further than $150 \mathrm{~km}$ offshore (Sparkes et al., 2015). A similar non-linear relationship is observed here between $R^{\prime}{ }_{\text {soil }}$ and BIT (Fig. 5b), as also previously demonstrated for the surface sediment offshore transect off the Kolyma River mouth (Doğrul Selver et al., 2015), indicating that similar processes are operating across the entire ESAS.

The simple linear correlation between $R^{\prime}$ soil and bulk carbon isotope values is intriguing as it suggests that, unlike the brGDGTs, which in this region are proposed to be primarily derived from fluvial transport (De Jonge et al., 2014; Doğrul Selver et al., 2015; Peterse et al., 2014; Sparkes et al., $2015)$, the $R^{\prime}$ soil proxy provides a more integrated signature of different terrestrial sources including ICD and fluvially transported topsoil-permafrost or riverine-produced material. Therefore, soil marker BHPs and brGDGTs, despite being nominally derived from similar sources, i.e. terrestrial microbial membrane lipids, appear in fact to be representing different aspects of terrestrial OC export.
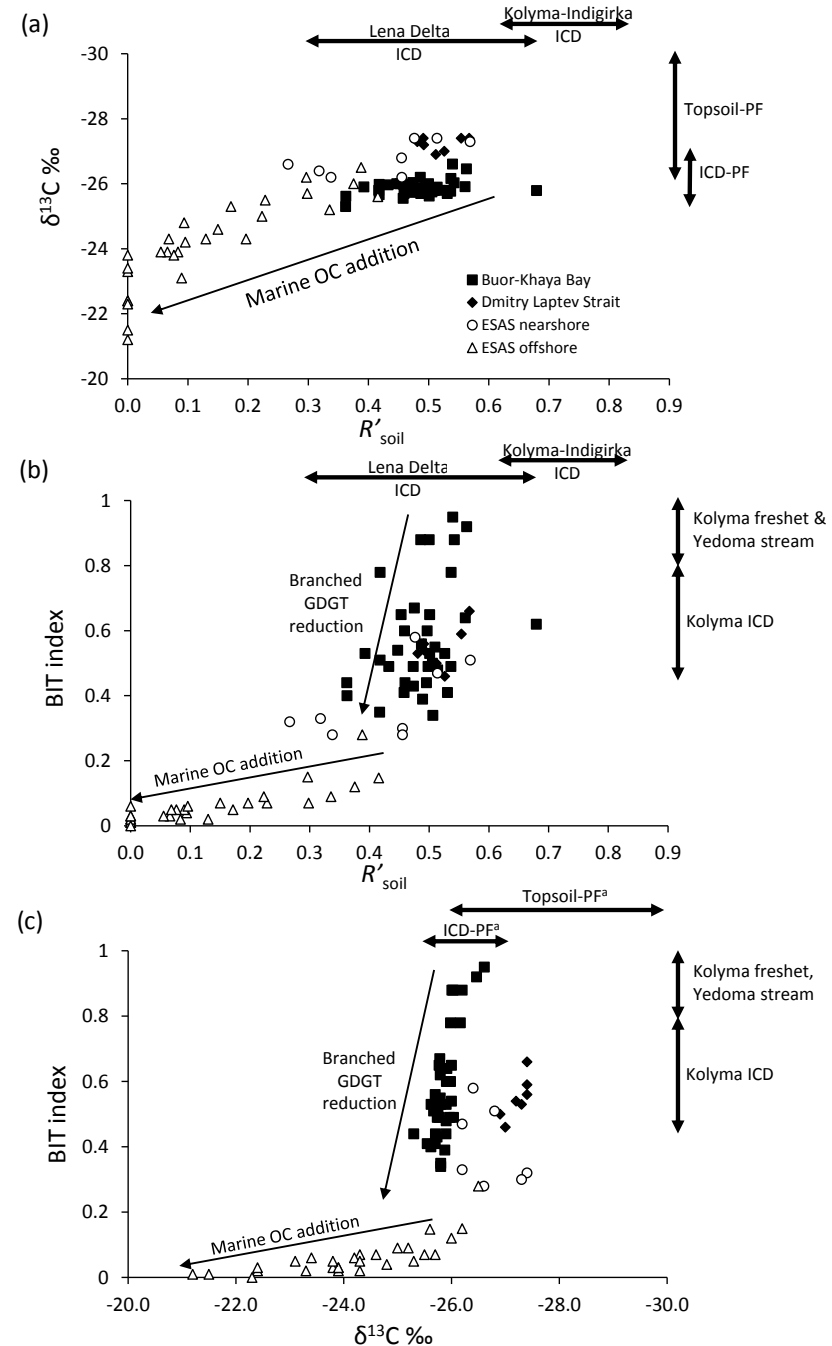

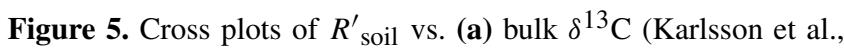
2011) and (b) BIT index (Sparkes et al., 2015) and (c) BIT index vs. $\delta^{13} \mathrm{C}$ in ESAS sediments. Typical values for terrestrial BIT index vs. $\delta^{13} \mathrm{C}$ endmembers are indicated $\left(R^{\prime}\right.$ soil - this study; $\delta^{13} \mathrm{C}$ - Vonk et al., 2012; BIT index - Bischoff, 2013 and Peterse et al., 2014). Note BHP and bulk carbon isotope plot shows linear mixing trend, whilst BIT index shows non-linear relationship to both other parameters; the BIT index drops significantly before a shift in

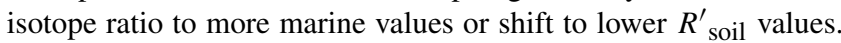
$R^{\prime}$ soil endmember values are lower than 1 due to presence of BHT in terrestrial materials (Table S3) and typically lower in the Lena River region $($ mean $=0.50)$ than in the eastern ESAS region (mean $=0.76) .{ }^{\mathrm{a}}$ ICD, ice complex deposit; PF, permafrost.

De Jonge et al. (2016) recently demonstrated that soil marker BHPs can indeed be transported in suspended particulate matter (SPM) from the Yenisei River, a large river located west of the ESAS. In the Yenisei study, only a moderate correlation was observed between the $\delta^{13} \mathrm{C}$ values and $R_{\text {soil }}^{\prime}\left(r^{2}=0.44, p<0.01\right)$, suggesting they trace different pools of OM (bulk terrigenous OM versus bacterial OM). 
However, unlike in the current study, De Jonge et al. (2016) also found a strong linear correlation between $R^{\prime}$ soil and BIT $\left(r^{2}=0.82, p<0.05\right)$. The Yenisei River catchment and outflow have significantly different characteristics to those of the rivers entering the ESAS, specifically in terms of the extent of different permafrost regimes. Permafrost is classified as isolated, sporadic, discontinuous and continuous according to its spatial distribution (e.g. Zhang et al., 2008). Continuous permafrost means that over $90 \%$ of the area is frozen in contrast to discontinuous permafrost, where only $30-80 \%$ of the area is underlain by permafrost. The Yenisei drains an area with a high proportion of discontinuous permafrost $(55 \%)$, whilst the proportion of continuous permafrost is lower (33\%; Feng et al., 2013, and references therein). The proportion of continuous permafrost in the eastern river catchments is higher, ranging from $79 \%$ (Lena) to $100 \%$ (Kolyma and Indigirka; Feng et al., 2015; and references therein). This may in turn affect the composition and preservation of terrestrial microbial markers. Indeed, previous work has indicated that OC from continuous permafrost areas is older but also less degraded and more biolabile than that from areas of discontinuous permafrost (e.g. Cooke et al., 2009; Feng et al., 2015; Mann et al., 2015; Spencer et al., 2015; van Dongen et al., 2008). Additionally, although there is some evidence of coastal erosion of ICD in this region, such as in the Khalmyer Bay area, this is not directly drained by the Yenisei River. Therefore, in this more westerly region it is likely that the primary source for both soil marker BHPs and brGDGTs is fluvial transport, hence the linear relationship between soil microbial biomarkers and bulk $\delta^{13} \mathrm{C}$ values (De Jonge et al., 2015, 2016). Whereas in the more easterly region we assume brGDGTs to be of fluvial origin (Sparkes et al., 2015) and the soil marker BHPs to have an integrated signature of terrestrial sources including ICD and fluvially transported topsoil-permafrost or riverine-produced material.

\subsection{Terrestrial endmembers and implications for ESAS sedimentary carbon budgets}

Given the apparent discrepancy between the BHP and GDGT-derived signals, further consideration of the terrestrial endmembers is clearly required. Although extensive databases exist for different bulk isotopic endmembers for the Arctic region (e.g. Tesi et al., 2014; Vonk et al., 2012; and references therein), data on the soil microbial lipid derived proxy values are limited for the Siberian region (see Table 1 for summary). Recently, Peterse et al. (2014) reported high BIT values for a range of materials from the Kolyma region (eastern ESAS), including thermokarst and floodplain lake sediments (BIT $=1$ ), yedoma (and associated streams; BIT $=0.81-0.89)$ and SPM from the Kolyma River including samples collected during the spring freshet (BIT $=0.99-1)$. However, Sparkes et al. (2015) reported values for three ICD (Yedoma) samples from the same area rang- ing from 0.44 to 0.7 . The lower values resulted from relatively high levels of crenarchaeol, which is unusual for terrestrial materials (typical BIT values $>0.8$; Schouten et al., 2013), although this compound has been reported from several Thaumarchaeota isolated from soil (Sinninghe Damsté et al., 2012). Data on BHPs from the (East Siberian) Arctic region are scarce as previous studies of terrestrial BHPs have primarily focused on temperate and more recently on tropical regions (see review in Spencer-Jones et al., 2015). Doğrul Selver et al. (2015) reported average $R^{\prime}$ soil values of 0.76 (range $0.70-0.84$ ) for the same three ICD yedoma samples from the Kolyma region (CHYED-2; Table 1, Table S3). Höfle et al. (2015) also reported the BHP composition in polygonal active layer deposits (to a maximum depth of $48 \mathrm{~cm}$ ) from two locations in the Lena Delta, Samoylov Island and Kurungnakh Island. Calculating $R_{\text {soil }}^{\prime}$ values from these data revealed a wide range of values from 0.18 to 0.79 and a mean average of 0.41 (Table 1). Although this simple average will likely not represent a spatially and depth resolved average for the region, it is still close to the mean values found in Buor-Khaya Bay and Dmitry Laptev Strait sediments (Table S2).

To further evaluate potential endmember ranges, additional ICD samples from the Lena, Indigirka and Kolyma regions were investigated for BHPs (Table S3). We analysed 23 samples from a $25 \mathrm{~m}$ permafrost core from Kurungnakh Island (see details in Bischoff et al., 2013) and an additional sample from Cape Bykovsky at $1.9 \mathrm{~m}$ depth (Table S3). BHT and a range of soil marker BHPs were present in all samples. BHT concentration ranged from 7 to $643 \mu \mathrm{g} \mathrm{g}_{\mathrm{OC}}^{-1}$ (mean average $248 \mu \mathrm{g} \mathrm{g}_{\mathrm{OC}}^{-1}$ ) in the Kurungnakh Island permafrost deposits. As in the ESAS sediments (Table S2), the soil marker BHPs included high proportions of adenosylhopane (1a), followed by adenosylhopane type 2 (1b) and adenosylhopane type 3 (1)') (mean average $250 \mu \mathrm{gg}_{\mathrm{OC}}^{-1}$; Table S3). As expected, observation of the methylated compounds was intermittent and then only at very low levels (Table S3), justifying their exclusion from $R^{\prime}$ soil (Doğrul Selver et al., 2012, $2015) . R^{\prime}$ soil values ranged from 0.37 to 0.64 with a mean value of 0.50 (Table 1), whilst the Cape Bykovsky (CB) sample had an $R^{\prime}$ soil of 0.68 (Table 1). The low $R^{\prime}$ soil values in ICD from this region $(0.34$ to 0.80 , mean 0.49 ; Figs. 3 c, 4$)$ are in excellent agreement with the mean and range of values found within the ISSS-08 Buor-Khaya Bay and Dmitry Laptev Strait sediments (0.49 and 0.52 respectively; Table S2; Fig. 5a). Although additional sources of BHPs from fluvial transport and from material transported via changes in hydrological conduits resulting from thermokarst erosion are also possible (POC; e.g. Vonk et al., 2015), there are currently no data on the BHP composition in this fraction from this region for comparison.

Bulk $\delta^{13} \mathrm{C}$ was not measured for the KUR core used in this study, but Wagner et al. (2007) reported values between -23.1 and $-24.6 \%$ or the OC fraction of selected per- 
Table 1. Mean, maximum and minimum values for OM proxy values $\left(R^{\prime}\right.$ soil, BIT and $\left.\delta^{13} \mathrm{C}\right)$ by sample group location and type of material.

\begin{tabular}{|c|c|c|c|c|c|c|c|c|c|c|c|c|}
\hline Location & $n^{\mathrm{a}}$ & $\begin{array}{c}R_{\text {soil }}^{\prime} \\
\text { (mean) }\end{array}$ & $\begin{array}{l}R_{\text {Soil }}^{\prime} \\
(\max )\end{array}$ & $\begin{array}{l}R_{\text {soil }}^{\prime} \\
(\mathrm{min})\end{array}$ & $n^{\mathrm{a}}$ & $\begin{array}{r}\text { BIT } \\
(\text { mean })\end{array}$ & $\begin{array}{r}\text { BIT } \\
(\max )\end{array}$ & $\begin{array}{r}\text { BIT } \\
(\min )\end{array}$ & $n^{\mathrm{a}}$ & $\begin{array}{r}\delta^{13} \mathrm{C} \\
\text { (mean) } \\
\% o\end{array}$ & $\begin{array}{r}\delta^{13} \mathrm{C} \\
(\max ) \\
\% o\end{array}$ & $\begin{array}{r}\delta^{13} \mathrm{C} \\
(\min ) \\
\% o\end{array}$ \\
\hline \multicolumn{13}{|l|}{ ISSS-08 sediments } \\
\hline Buor-Khaya Bay & 47 & 0.49 & 0.80 & 0.34 & $47^{b}$ & 0.58 & 0.95 & 0.26 & $37^{\mathrm{c}}$ & -25.9 & -25.3 & -26.6 \\
\hline Dmitry Laptev Strait & 7 & 0.52 & 0.57 & 0.48 & $7^{\mathrm{b}}$ & 0.55 & 0.66 & 0.46 & $7^{c}$ & -27.2 & -26.9 & -27.4 \\
\hline ESAS nearshore & 9 & 0.41 & 0.57 & 0.27 & $9^{b}$ & 0.35 & 0.58 & 0.10 & $8^{c}$ & -26.8 & -26.2 & -27.4 \\
\hline ESAS offshore & 29 & 0.14 & 0.42 & 0.00 & $29^{b}$ & 0.06 & 0.28 & 0.00 & $28^{\mathrm{c}}$ & -24.2 & -21.2 & -26.5 \\
\hline \multicolumn{13}{|l|}{ Ice complex } \\
\hline Lena Delta (KUR) & 23 & 0.50 & 0.64 & 0.37 & $23^{d}$ & 0.97 & 1.0 & 0.87 & 23 & n.d. ${ }^{\mathrm{e}}$ & n.d. & n.d \\
\hline Cape Bykovsky & 1 & 0.68 & & & 1 & n.d. & & & 1 & -26.0 & & \\
\hline Kolyma+Indigirka & 11 & 0.76 & 0.84 & 0.62 & $3^{b}$ & 0.53 & 0.7 & 0.44 & 5 & -24.3 & -23.02 & -25.8 \\
\hline \multicolumn{13}{|l|}{ Literature data } \\
\hline ICD permafrost & & & & & & & & & $374^{\mathrm{c}}$ & $-26.3 \pm 0.7^{\mathrm{f}}$ & & \\
\hline Topsoil permafrost & & & & & & & & & $20^{\mathrm{c}}$ & $-28.2 \pm 2.0^{f}$ & & \\
\hline Yedoma (Duvanny Yar) & & & & & $1^{\mathrm{g}}$ & 0.82 & & & & & & \\
\hline Yedoma stream (Duvanny Yar) & & & & & $8^{g}$ & 0.83 & 0.89 & 0.81 & & & & \\
\hline SPM (Kolyma River) & & & & & $6^{\mathrm{g}}$ & & 1.0 & 0.99 & & & & \\
\hline Lena Delta permafrost soils & $24^{\mathrm{h}}$ & 0.41 & 0.79 & 0.18 & & & & & & & & \\
\hline
\end{tabular}

a $n$, number of samples used for calculation of mean for individual parameters;

b data from Sparkes et al. (2015);

c data from Vonk et al. (2012);

d data from Bischoff (2013)

e n.d., not determined;

$\mathrm{f}$ mean \pm standard deviation;

$\mathrm{g}$ data from Peterse et al. (2014);

$\mathrm{h}$ data from Höfle et al. (2015).

mafrost sediments from Samoylov Island, which lies close to Kurungnakh Island in the Lena Delta (see map in Höfle et al., 2015). These values from Samoylov Island are significantly enriched relative to the value for the Cape Bykovsky sample (-26.0\%; Table S3) and may be because these deposits are genetically different (Holocene fluvial sediments vs. Pleistocene ICD) or reflect input from aquatic plants in low-centre polygon ponds (Schirrmeister et al., 2011). However, input from peat, grasses, herbs and shrubs results in more negative values such as those reported by Schirrmeister et al. (2011) for a range of sites in the region including Kurungnakh Island and the Bykovsky Peninsula (range -30 to $-25 \%$ ). The $\delta^{13} \mathrm{C}$ values for the ISSS-08 sediments from Buor-Khaya Bay ( -25.3 to $-26.6 \%$ ) and the Dmitry Laptev Strait $(-26.9$ to $-27.4 \%$ o $)$ therefore suggest a significant contribution of terrestrial material. Vonk et al. (2012) reported an extensive compilation of circum-Arctic literature data with an average $\delta^{13} \mathrm{C}$ value of $-26.3 \pm 0.7 \%$ o for ICD OC (coastal, inland and sub-sea; formed before inundation) and even more depleted values for topsoil permafrost with $\delta^{13} \mathrm{C}$ of $-28.2 \pm 2.0 \%$ (Table 1). By combining bulk ${ }^{13} \mathrm{C}$ and ${ }^{14} \mathrm{C}$ data, these authors estimated the proportion of sedimentary OM derived from ICD, topsoil and marine sources, with over two-thirds of the OM in Buor-Khaya Bay derived from terrestrial sources and even higher values in Dmitry
Laptev Strait sediments. These terrestrial OM estimates can now be compared to estimates based on the BHP concentrations/compositions obtained using a similar approach with the results from the ICD samples as the terrestrial endmembers.

ICD samples from the Indigirka $(n=3)$ and Kolyma River $(n=8)$ regions had lower absolute concentrations of BHPs (BHT range 8.5 to $62 \mu \mathrm{gg}_{\mathrm{OC}}^{-1}$; non-methylated soil markers range from 43 to $123 \mu \mathrm{g} \mathrm{g}_{\mathrm{OC}}^{-1}$ ) and generally higher $R^{\prime}$ soil values than those from the Lena region (mean 0.76, range 0.620.84; Tables 1, S3; Fig. 5a). Although there are some differences in the relative abundances of the non-methylated soil markers BHPs between the different regions (Table S4), in all cases BHP 1a was the most abundant, followed by BHP $\mathbf{1 b}$ and minor relative amounts of BHP 1b' (see Table S4). Correlation of concentrations of all three pairs of these nonmethylated soil markers (BHP 1a vs. BHP 1b, BHP 1b vs. BHP 1b' and BHP 1a vs. BHP 1b') in all ICD samples gives an $r^{2}>0.6$ and $p$ value $<0.001$ for each pair of compounds. This shows that the distribution of the non-methylated soil markers in all ICD samples is comparable across the East Siberian Arctic region. Given the higher $R^{\prime}$ soil values for ICD in the eastern region, this suggests that although some removal of soil marker BHPs may have already occurred in the river estuaries before reaching the near-coastal shelf sed- 
iments, a significant proportion remains intact. Based on the range of ICD permafrost endmember data for the Kolyma and Indigirka samples, this would suggest that 58 to $92 \%$ of the OC derived from terrestrial OM (e.g. \% ICD and topsoil) at the start of the offshore Kolyma River mouth surface sediment transect (sample YS-34B, $R^{\prime}$ soil $=0.57$ ) and 49 to $77 \%$ of the OC derived from terrestrial OM at the start of the offshore transect off the Indigirka River mouth (sample YS$30, R_{\text {soil }}^{\prime}=0.48$ ) is of terrestrial origin. These values should be treated with caution given the limited number of samples involved, but are close to the average value reported for the ESAS surface sediments based on dual-carbon-isotope $\left(\delta^{13} \mathrm{C}\right.$ and $\left.\Delta{ }^{14} \mathrm{C}\right)$ mixing models $(75 \pm 14 \%$ from terrestrial origin; Vonk et al., 2012).

This difference in $R^{\prime}$ soil values in permafrost deposits/ICDs across the East Siberian Arctic region is likely due to two separate regional provinces, both underlain by mostly continuous permafrost, but with permafrost deposits of different ages and formation mechanisms (Schirrmeister et al., 2011). Further, samples in the western and far eastern region are subject to different environmental conditions (with colder and drier conditions in the far eastern region (Gordeev, 1996), potentially indicating better preservation of the structurally more complex soil marker BHPs relative to BHT (see Sect. 3.2). This agrees with previous studies which have also found better preservation of more highly functionalised and biolabile molecules in materials from the eastern region (e.g. Guo et al., 2004; van Dongen et al., 2008). Tesi et al. (2016) reported that fine and ultrafine grain size fractions contain a high proportion of high-molecular-weight lipid markers which are preferably bound to the mineral matrix and that the reactivity of lipid biomarkers on the ESAS seems to be lower and inversely proportional to the number of functional groups (cutin acids $>n$-alkanolic acid $>n$-alkanols $>n$ alkanes). Even though the reactivity for different BHPs is currently unknown, this points towards a potential recalcitrance of highly functionalised BHP molecules on the ESAS. Furthermore, studies from soils have shown the potential for mineral-organic interactions, leading to increased resistance to degradation for aromatic compounds (Mikutta et al., 2007, 2009). Adenosylhopane, the most abundant single soil marker BHP on the ESAS, is the only BHP containing an aromatic moiety (adenine). Although Höfle et al. (2013) found organic-mineral associations to be of minor importance in the polygonal tundra of the Lena Delta, organic-mineral interactions may still be among several factors explaining the high relative abundance of these compounds under certain conditions.

However, the current sample set discussed is limited given the enormous spatial scale and extremely heterogeneous nature of these environments and does not include, for example, material released from thermokarst environments, including thermokarst lake sediments, which can be an important source of OC and inorganic material (Vonk et al., 2015). Furthermore, environmental parameters other than location (and inferred temperature) must also be considered as potentially affecting the overall BHP assemblage. For example, Höfle et al. (2015) recently demonstrated using principal component analysis that increasing $\mathrm{pH}$, over a range of 4.5 to 6.7 , was positively correlated with soil marker BHP concentration in Lena Delta permafrost, which is in close proximity $(<10 \mathrm{~km})$ to the site of the KUR core studied here. These authors proposed that this might indicate source organisms do not need to further extend their BHP side chains to alter membrane architecture at near-neutral conditions. Furthermore, studies of temperate Sphagnum peat deposits, which typically have low $\mathrm{pH}$ values, show low abundance of soil marker compounds relative to total BHPs when compared to mineral soils, but have higher abundance of BHT resulting in very low $R^{\prime}$ soil values (mean 0.4; calculated from data in van Winden et al., 2012a, b). This could suggest that, in areas with a significant input from peat-derived material in some areas/layers of the Lena Delta ICD (Bischoff et al., 2013; Wagner et al., 2007), lower $R^{\prime}{ }_{\text {soil }}$ values should be expected in agreement with observations in this study (Table S3). Indeed, $\mathrm{pH}$ has also been shown to play a dominant role in shaping bacterial communities with the capacity to produce hopanoids in an acidic peatland (Gong et al., 2015). Clearly a more comprehensive assessment of different terrestrial endmembers across the region is required, as are additional studies on primary environmental factors affecting BHP biosynthesis in culture. For example, to date no studies have investigated biosynthesis of adenosylhopane in psychrophilic/psychrotolerant organisms at different temperatures or at different growth stages, and studies of BHPs in association with $\mathrm{pH}$ adaptation have yet to measure adenosylhopane abundances (e.g. Welander et al., 2009). Given that adenosylhopane is the precursor for biosynthesis of all other side-chain extended BHPs (Bradley et al., 2010), it is possible that, under conditions of stress (such as extreme temperature and nutrient limitation), production of adenosylhopane without further modification is sufficient and/or all that some organisms are capable of and further modification is metabolically unfavourable/unnecessary.

\section{Conclusions}

Different suites of terrigenous microbial membrane lipids (biohopanoids and brGDGTs) and bulk carbon isotopes were used to trace the source and transport of terrestrial OC on the ESAS. As expected, ESAS sediments are terrestrially dominated; however, BHP- and GDGT-based SOM proxies are decoupled in Buor-Khaya Bay, southeastern Laptev Sea and across the ESAS, in agreement with an earlier pilot study of the surface sediment offshore transect off the Kolyma River mouth (Doğrul Selver et al., 2015). This is likely due to different sources, transport and/or degradation pathways for the various lipids. In particular, whilst brGDGTs have previously been shown to be primarily delivered to the ESAS via fluvial 
transport (Sparkes et al., 2015), BHPs appear to provide a more integrated signature correlating linearly with bulk carbon isotope ratios as well as distance from river mouths. The BHP terrestrial endmembers, i.e. adenosylhopane and other soil marker BHPs, are significant components of coastal ICD which are transferred to ESAS sediments during coastal erosion. $R_{\text {soil }}^{\prime}$ proxy values, although still limited for this region, vary widely with on average significantly lower values occurring to the western range of East Siberia (average 0.5 for the Lena Delta ICD) and higher values further east (average 0.76 for Indigirka and Kolyma ICD). The controlling factors responsible for this difference may include factors such as depositional history and age of permafrost deposits, mineral grain size, environmental/abiotic factors (e.g. temperature, precipitation and $\mathrm{pH}$ ), and microbial/metabolic factors under psychrophilic conditions and require further investigation.

\section{Data availability}

Data used in this article can be found in the Supplement.

\section{The Supplement related to this article is available online at doi:10.5194/bg-13-4899-2016-supplement.}

Author contributions. Ö. Gustafsson, B. E. van Dongen, O. V. Dudarev, and I. P. Semiletov collected samples along with the crew of ISSS-08. Ice complex samples were collected and provided by R. G. M. Spencer, E. Rivkina, D. Wagner and A. N. Kurchatova. H. M. Talbot and B. E. van Dongen designed the study, which was carried out by J. Bischoff, with assistance from R. B. Sparkes and A. Doğrul Selver. H. M. Talbot, J. Bischoff, R. B. Sparkes and B. E. van Dongen prepared the manuscript with contributions from all co-authors.

Acknowledgements. We gratefully acknowledge receipt of a NERC research grant (NE/I024798/1 and NE/I027967/1) to B. E. van Dongen and H. M. Talbot, a Ph.D. studentship to A. Doğrul Selver funded by the Ministry of National Education of Turkey, financial support as an Academy Research Fellow to Ö. Gustafsson from the Swedish Royal Academy of Sciences through a grant from the Knut and Alice Wallenberg Foundation and support from the Government of the Russian Federation (grant \#14, Z50.31.0012/03.19.2014) to I. Semiletov and from the Russian Scientific Foundation to O. Dudarev (grant \# 15-17-20032). We thank the crew and personnel of the R/V Yakob Smirnitsky and all colleagues in the International Siberian Shelf Study (ISSS) programme for support, including sampling. We thank A. N. Kurchatova for assistance with fieldwork on Kurungnakh Island and T. Tesi for providing the Yedoma samples for the Kolyma and Indigirka catchment areas. We thank P. Lythgoe (University of Manchester) and F. Sidgwick (Newcastle University) for invaluable assistance with LCMS and the Science Research Investment Fund (SRIF) from HEFCE for the Thermo Finnigan LCQ ion trap mass spectrometer (Newcastle University). R. G. M. Spencer was partially supported by the U.S. National Science Foundation (ANT1203885/PLR-1500169). The ISSS programme is supported by the Knut and Alice Wallenberg Foundation, the Far Eastern Branch of the Russian Academy of Sciences, the Swedish Research Council, the US National Oceanic and Atmospheric Administration, the Russian Foundation of Basic Research, the Swedish Polar Research Secretariat, the Nordic Council of Ministers and the US National Science Foundation. Finally, we thank the associate editor and the two anonymous reviewers for constructive suggestions.

Edited by: J. Middelburg

Reviewed by: two anonymous referees

\section{References}

Bednarczyk, A., Hernandez, T. C., Schaeffer, P., Adam, P., Talbot, H. M., Farrimond, P., Riboulleau, A., Largeau, C., Derenne, S., Rohmer, M., and Albrecht, P.: 32,35Anhydrobacteriohopanetetrol: an unusual bacteriohopanepolyol widespread in recent and past environments, Organic Geochem., 36, 673-677, doi:10.1016/j.orggeochem.2004.10.014, 2005.

Bischoff, J.: Microbial communities and their response to Pleistocene and Holocene climate variabilities in the Russian Arctic, Ph.D. thesis, 2013.

Bischoff, J., Mangelsdorf, K., Gattinger, A., Schloter, M., Kurchatova, A. N., Herzschuh, U., and Wagner, D.: Response of methanogenic archaea to Late Pleistocene and Holocene climate changes in the Siberian Arctic, Global Biogeochem. Cy., 27, 305-317, doi:10.1029/2011GB004238, 2013.

Bligh, E. G. and Dyer, W. J.: A rapid method of total lipid extraction and purification, Can. J. Biochem. Physiol., 37, 911-917, doi:10.1139/o59-099, 1959.

Blumenberg, M., Seifert, R., Kasten, S., Bahlmann, E., and Michaelis, W.: Euphotic zone bacterioplankton sources major sedimentary bacteriohopanepolyols in the Holocene Black Sea, Geochim. Cosmochim. Acta, 73, 750-766, doi:10.1016/j.gca.2008.11.005, 2009.

Blumenberg, M., Mollenhauer, G., Zabel, M., Reimer, A., and Thiel, V.: Decoupling of bio- and geohopanoids in sediments of the Benguela Upwelling System (BUS), Organic Geochem., 41, 1119-1129, doi:10.1016/j.orggeochem.2010.06.005, 2010.

Blumenberg, M., Berndmeyer, C., Moros, M., Muschalla, M., Schmale, O., and Thiel, V.: Bacteriohopanepolyols record stratification, nitrogen fixation and other biogeochemical perturbations in Holocene sediments of the central Baltic Sea, Biogeosciences, 10, 2725-2735, doi:10.5194/bg-10-2725-2013, 2013.

Bradley, A. S., Pearson, A., Sáenz, J. P., and Marx, C. J.: Adenosylhopane: The first intermediate in hopanoid side chain biosynthesis, Organic Geochem., 41, 1075-1081, doi:10.1016/j.orggeochem.2010.07.003, 2010.

Cooke, M. P., Talbot, H. M., and Farrimond, P.: Bacterial populations recorded in bacteriohopanepolyol distributions in soils from Northern England, Organic Geochem., 39, 1347-1358, doi:10.1016/j.orggeochem.2008.05.003, 2008a. 
Cooke, M. P., Talbot, H. M., and Wagner, T.: Tracking soil organic carbon transport to continental margin sediments using soil-specific hopanoid biomarkers: A case study from the Congo fan (ODP site 1075), Organic Geochem., 39, 965-971, doi:10.1016/j.orggeochem.2008.03.009, 2008b.

Cooke, M. P., van Dongen, B. E., Talbot, H. M., Semiletov, I., Shakhova, N., Guo, L., and Gustafsson, O.: Bacteriohopanepolyol biomarker composition of organic matter exported to the Arctic Ocean by seven of the major Arctic rivers, Organic Geochem., 40, 1151-1159, doi:10.1016/j.orggeochem.2009.07.014, 2009.

Coolen, M. J. L., Talbot, H. M., Abbas, B. A., Ward, C., Schouten, S., Volkman, J. K., and Damsté, J. S. S.: Sources for sedimentary bacteriohopanepolyols as revealed by $16 \mathrm{~S}$ rDNA stratigraphy, Environ. Microbiol., 10, 1783-1803, doi:10.1111/j.14622920.2008.01601.x, 2008.

De Jonge, C., Stadnitskaia, A., Hopmans, E. C., Cherkashov, G., Fedotov, A., and Sinninghe Damsté, J. S.: In situ produced branched glycerol dialkyl glycerol tetraethers in suspended particulate matter from the Yenisei River, Eastern Siberia, Geochim. Cosmochim. Acta, 125, 476-491, doi:10.1016/j.gca.2013.10.031, 2014.

De Jonge, C., Stadnitskaia, A., Hopmans, E. C., Cherkashov, G., Fedotov, A., Streletskaya, I. D., Vasiliev, A. A., and Sinninghe Damsté, J. S.: Drastic changes in the distribution of branched tetraether lipids in suspended matter and sediments from the Yenisei River and Kara Sea (Siberia): Implications for the use of brGDGT-based proxies in coastal marine sediments, Geochim. Cosmochim. Acta, 165, 200-225, doi:10.1016/j.gca.2015.05.044, 2015.

De Jonge, C., Talbot, H. M., Bischoff, J., Stadnitskaia, A., Cherkashov, G., and Sinninghe Damsté, J. S.: Bacteriohopanepolyol distribution in Yenisei River and Kara Sea suspended particulate matter and sediments traces terrigenous organic matter input, Geochim. Cosmochim. Acta, 174, 85-101, doi:10.1016/j.gca.2015.11.008, 2016.

Dittmar, T. and Kattner, G.: The biogeochemistry of the river and shelf ecosystem of the Arctic Ocean: a review, Mar. Chem., 83, 103-120, doi:10.1016/S0304-4203(03)00105-1, 2003.

Doğrul Selver, A., Talbot, H. M., Gustafsson, O., Boult, S., and van Dongen, B. E.: Soil organic matter transport along an sub-Arctic river-sea transect, Organic Geochem., 51, 63-72, doi:10.1016/j.orggeochem.2012.08.002, 2012.

Doğrul Selver, A., Sparkes, R. B., Bischoff, J., Talbot, H. M., Gustafsson, Ö., Semiletov, I. P., Dudarev, O. V., Boult, S., and van Dongen, B. E.: Distributions of bacterial and archaeal membrane lipids in surface sediments reflect differences in input and loss of terrestrial organic carbon along a cross-shelf Arctic transect, Organic Geochem., 83-84, 16-26, doi:10.1016/j.orggeochem.2015.01.005, 2015.

Drake, T. W., Wickland, K. P., Spencer, R. G. M., McKnight, D. M., and Striegl, R. G.: Ancient low-molecular-weight organic acids in permafrost fuel rapid carbon dioxide production upon thaw, P. Natl. Acad. Sci., 112, 13946-13951, doi:10.1073/pnas.1511705112, 2015.

Drenzek, N. J., Montluçon, D. B., Yunker, M. B., Macdonald, R. W., and Eglinton, T. I.: Constraints on the origin of sedimentary organic carbon in the Beaufort Sea from coupled molec- ular 13C and 14C measurements, Mar. Chem., 103, 146-162, doi:10.1016/j.marchem.2006.06.017, 2007.

Feng, X., Vonk, J. E., van Dongen, B. E., Gustafsson, Ö., Semiletov, I. P., Dudarev, O. V., Wang, Z., Montluçon, D. B., Wacker, L., and Eglinton, T. I.: Differential mobilization of terrestrial carbon pools in Eurasian Arctic river basins, P. Natl. Acad. Sci., 110, 14168-14173, doi:10.1073/pnas.1307031110, 2013.

Feng, X., Gustafsson, Ö., Holmes, R. M., Vonk, J. E., van Dongen, B. E., Semiletov, I. P., Dudarev, O. V., Yunker, M. B., Macdonald, R. W., Montluçon, D. B., and Eglinton, T. I.: Multi-molecular tracers of terrestrial carbon transfer across the pan-Arctic: comparison of hydrolyzable components with plant wax lipids and lignin phenols, Biogeosciences, 12, 4841-4860, doi:10.5194/bg12-4841-2015, 2015.

Gong, L., Wang, H., Xiang, X., Qiu, X., Liu, Q., Wang, R., Zhao, R., and Wang, C.: pH Shaping the Composition of sqhCContaining Bacterial Communities, Geomicrobiol. J., 32, 433444, doi:10.1080/01490451.2014.950363, 2015.

Goñi, M. A., Yunker, M. B., Macdonald, R. W., and Eglinton, T. I.: The supply and preservation of ancient and modern components of organic carbon in the Canadian Beaufort Shelf of the Arctic Ocean, Mar. Chem., 93, 53-73, doi:10.1016/j.marchem.2004.08.001, 2005.

Gordeev, V.: A reassessment of the Eurasian river input of water, sediment, major elements, and nutrients to the Arctic Ocean, Am J. Sci., 296, 664-691, doi:10.2475/ajs.296.6.664, 1996.

Gordeev, V. V.: Fluvial sediment flux to the Arctic Ocean, Geomorphology, 80, 94-104, doi:10.1016/j.geomorph.2005.09.008, 2006.

Grigoriev, M.: Russian-German cooperation SYSTEM LAPTEV SEA: the expedition LENA 2002, Tech. rep., 2003.

Guo, L., Semiletov, I., Gustafsson, Ö., Ingri, J., Andersson, P., Dudarev, O., and White, D.: Characterization of Siberian Arctic coastal sediments: Implications for terrestrial organic carbon export, Global Biogeochem. Cy., 18, GB1036, doi:10.1029/2003GB002087, 2004.

Gustafsson, Ö., van Dongen, B. E., Vonk, J. E., Dudarev, O. V., and Semiletov, I. P.: Widespread release of old carbon across the Siberian Arctic echoed by its large rivers, Biogeosciences, 8, 1737-1743, doi:10.5194/bg-8-1737-2011, 2011.

Handley, L., Talbot, H. M., Cooke, M. P., Anderson, K., and Wagner, T.: Novel records of past methane emission events from the Congo and Amazon fans, Geochim. Cosmochim. Acta, 74, A379-A379, 2010.

Harris, D., Horwáth, W. R., and van Kessel, C.: Acid fumigation of soils to remove carbonates prior to total organic carbon or CARBON-13 isotopic analysis, Soil Sci. Soc. Am. J., 65, 1853 1856, doi:10.2136/sssaj2001.1853, 2001.

Hayes, J. M.: Factors controlling 13C contents of sedimentary organic compounds: Principles and evidence, Mar. Geol., 113, 111-125, doi:10.1016/0025-3227(93)90153-M, 1993.

Höfle, S., Rethemeyer, J., Mueller, C. W., and John, S.: Organic matter composition and stabilization in a polygonal tundra soil of the Lena Delta, Biogeosciences, 10, 3145-3158, doi:10.5194/bg10-3145-2013, 2013.

Höfle, S. T., Kusch, S., Talbot, H. M., Mollenhauer, G., Zubrzycki, S., Burghardt, S., and Rethemeyer, J.: Characterisation of bacterial populations in Arctic permafrost soils 
using bacteriohopanepolyols, Organic Geochem., 88, 1-16, doi:10.1016/j.orggeochem.2015.08.002, 2015.

Holmes, R. M., McClelland, J. W., Peterson, B. J., Tank, S. E., Bulygina, E., Eglinton, T. I., Gordeev, V. V., Gurtovaya, T. Y., Raymond, P. A., Repeta, D. J., Staples, R., Striegl, R. G., Zhulidov, A. V., and Zimov, S. A.: Seasonal and Annual Fluxes of Nutrients and Organic Matter from Large Rivers to the Arctic Ocean and Surrounding Seas, Estuar. Coasts, 35, 369-382, doi:10.1007/s12237-011-9386-6, 2012.

Holmes, R. M., Coe, M. T., Fiske, G. J., Gurtovaya, T., McClelland, J. W., Shiklomanov, A. I., Spencer, R. G. M., Tank, S. E., and Zhulidov, A. V.: Climate Change Impacts on the Hydrology and Biogeochemistry of Arctic Rivers, in: Climatic Change and Global Warming of Inland Waters, 1-26, John Wiley \& Sons, Ltd, doi:10.1002/9781118470596.ch1, 2013.

Hopmans, E. C., Weijers, J. W. H., Schefuss, E., Herfort, L., Damste, J. S. S., and Schouten, S.: A novel proxy for terrestrial organic matter in sediments based on branched and isoprenoid tetraether lipids, Earth Planet. Sci. Lett., 224, 107-116, doi:10.1016/j.epsl.2004.05.012, 2004

Hugelius, G., Strauss, J., Zubrzycki, S., Harden, J. W., Schuur, E. A. G., Ping, C.-L., Schirrmeister, L., Grosse, G., Michaelson, G. J., Koven, C. D., O’Donnell, J. A., Elberling, B., Mishra, U., Camill, P., Yu, Z., Palmtag, J., and Kuhry, P.: Estimated stocks of circumpolar permafrost carbon with quantified uncertainty ranges and identified data gaps, Biogeosciences, 11, 6573-6593, doi:10.5194/bg-11-6573-2014, 2014.

IPCC: Climate Change 2013: The Physical Science Basis. Contribution of Working Group I to the Fifth Assessment Report of the Intergovernmental Panel on Climate Change, Cambridge University Press, Cambridge, United Kingdom and New York, NY, USA, 2013.

Karlsson, E. S., Charkin, A., Dudarev, O., Semiletov, I., Vonk, J. E., Sánchez-García, L., Andersson, A., and Gustafsson, Ö.: Carbon isotopes and lipid biomarker investigation of sources, transport and degradation of terrestrial organic matter in the Buor-Khaya Bay, SE Laptev Sea, Biogeosciences, 8, 1865-1879, doi:10.5194/bg-8-1865-2011, 2011.

Kim, J.-H., Talbot, H. M., Zarzycka, B., Bauersachs, T., and Wagner, T.: Occurrence and abundance of soil-specific bacterial membrane lipid markers in the Têt watershed (southern France): Soil-specific BHPs and branched GDGTs, Geochemistry, Geophysics, Geosystems, 12, Q02008, doi:10.1029/2010GC003364, 2011.

Knoblauch, C., Beer, C., Sosnin, A., Wagner, D., and Pfeiffer, E.M.: Predicting long-term carbon mineralization and trace gas production from thawing permafrost of Northeast Siberia, Glob. Change Biol., 19, 1160-1172, doi:10.1111/gcb.12116, 2013.

Kotlyakov, V. and Khromova, T.: Maps of Permafrost and Ground Ice, Version 1, in: Land Resources of Russia, Laxenburg, Austria: International Institute for Applied Systems Analysis and the Russian Academy of Science, CD-ROM, Distributed by the National Snow and Ice Data Center, Boulder, 2002.

Lantuit, H., Atkinson, D., Overduin, P. P., Grigoriev, M., Rachold, V., Grosse, G., and Hubberten, H.-W.: Coastal erosion dynamics on the permafrost-dominated Bykovsky Peninsula, north Siberia, 1951-2006, 2011, doi:10.3402/polar.v30i0.7341, 2011.

Lantuit, H., Overduin, P. P., Couture, N., Wetterich, S., Aré, F., Atkinson, D., Brown, J., Cherkashov, G., Drozdov, D., Forbes,
D. L., Graves-Gaylord, A., Grigoriev, M., Hubberten, H.-W., Jordan, J., Jorgenson, T., Ødegård, R. S., Ogorodov, S., Pollard, W. H., Rachold, V., Sedenko, S., Solomon, S., Steenhuisen, F., Streletskaya, I., and Vasiliev, A.: The Arctic Coastal Dynamics Database: A New Classification Scheme and Statistics on Arctic Permafrost Coastlines, Estuar. Coasts, 35, 383-400, doi:10.1007/s12237-010-9362-6, 2012.

Lantuit, H., Overduin, P. P., and Wetterich, S.: Recent Progress Regarding Permafrost Coasts, Permafrost and Periglacial Processes, 24, 120-130, doi:10.1002/ppp.1777, 2013.

Lupascu, M., Wadham, J. L., Hornibrook, E. R. C., and Pancost, R. D.: Methanogen Biomarkers in the Discontinuous Permafrost Zone of Stordalen, Sweden, Permafrost and Periglacial Processes, 25, 221-232, doi:10.1002/ppp.1823, 2014.

Mann, P. J., Eglinton, T. I., McIntyre, C. P., Zimov, N., Davydova, A., Vonk, J. E., Holmes, R. M., and Spencer, R. G. M.: Utilization of ancient permafrost carbon in headwaters of Arctic fluvial networks, Nature Communications, 6, 7856, doi:10.1038/ncomms8856, 2015.

Meyers, P. A.: Organic geochemical proxies of paleoceanographic, paleolimnologic, and paleoclimatic processes, Organic Geochem., 27, 213-250, doi:10.1016/S0146-6380(97)00049-1, 1997.

Mikutta, R., Mikutta, C., Kalbitz, K., Scheel, T., Kaiser, K., and Jahn, R.: Biodegradation of forest floor organic matter bound to minerals via different binding mechanisms, Geochim. Cosmochim. Acta, 71, 2569-2590, doi:10.1016/j.gca.2007.03.002, 2007.

Mikutta, R., Schaumann, G. E., Gildemeister, D., Bonneville, S., Kramer, M. G., Chorover, J., Chadwick, O. A., and Guggenberger, G.: Biogeochemistry of mineral-organic associations across a long-term mineralogical soil gradient (0.3-4100 kyr), Hawaiian Islands, Geochim. Cosmochim. Acta, 73, 2034-2060, doi:10.1016/j.gca.2008.12.028, 2009.

Opsahl, S., Benner, R., and Amon, R. M. W.: Major flux of terrigenous dissolved organic matter through the Arctic Ocean, Limnol. Oceanogr., 44, 2017-2023, doi:10.4319/lo.1999.44.8.2017, 1999.

Peterse, F., Vonk, J. E., Holmes, R. M., Giosan, L., Zimov, N., and Eglinton, T. I.: Branched glycerol dialkyl glycerol tetraethers in Arctic lake sediments: Sources and implications for paleothermometry at high latitudes, J. Geophys. Res.-Biogeosci., 119, 1738-1754, doi:10.1002/2014JG002639, 2014.

Peterson, B. J., Holmes, R. M., McClelland, J. W., Vörösmarty, C. J., Lammers, R. B., Shiklomanov, A. I., Shiklomanov, I. A., and Rahmstorf, S.: Increasing River Discharge to the Arctic Ocean, Science, 298, 2171-2173, doi:10.1126/science.1077445, 2002.

Rawlins, M. A., Steele, M., Holland, M. M., Adam, J. C., Cherry, J. E., Francis, J. A., Groisman, P. Y., Hinzman, L. D., Huntington, T. G., Kane, D. L., Kimball, J. S., Kwok, R., Lammers, R. B., Lee, C. M., Lettenmaier, D. P., McDonald, K. C., Podest, E., Pundsack, J. W., Rudels, B., Serreze, M. C., Shiklomanov, A., Â ystein Skagseth, Troy, T. J., Varasmarty, C. J., Wensnahan, M., Wood, E. F., Woodgate, R., Yang, D., Zhang, K., and Zhang, T.: Analysis of the Arctic System for Freshwater Cycle Intensification: Observations and Expectations, J. Climate, 23, 5715-5737, doi:10.1175/2010JCLI3421.1, 2010. 
Rethemeyer, J., Schubotz, F., Talbot, H. M., Cooke, M. P., Hinrichs, K.-U., and Mollenhauer, G.: Distribution of polar membrane lipids in permafrost soils and sediments of a small high Arctic catchment, Organic Geochem., 41, 1130-1145, doi:10.1016/j.orggeochem.2010.06.004, 2010.

Rohmer, M.: The biosynthesis of the triterpenoids of the hopane series in the Eubacteria: A mine of new enzyme reactions, Pure Appl. Chem., 65, 1293-1298, doi:10.1351/pac199365061293, 1993.

Romanovsky, V. E., Smith, S. L., and Christiansen, H. H.: Permafrost Thermal State in the Polar Northern Hemisphere during the International Polar Year 2007-2009: a Synthesis, Permafrost and Periglacial Processes, 21, 106-116, doi:10.1002/ppp.689, 2010.

Rush, D., Sinninghe Damsté, J. S., Poulton, S. W., Thamdrup, B., Garside, A. L., Acuña González, J., Schouten, S., Jetten, M. S. M., and Talbot, H. M.: Anaerobic ammonium-oxidising bacteria: A biological source of the bacteriohopanetetrol stereoisomer in marine sediments, Geochim. Cosmochim. Acta, 140, 50-64, doi:10.1016/j.gca.2014.05.014, 2014.

Savelieva, N. I., Semiletov, I. P., Vasilevskaya, L. N., and Pugach, S. P.: A climate shift in seasonal values of meteorological and hydrological parameters for Northeastern Asia, Prog. Oceanogr., 47, 279-297, doi:10.1016/S0079-6611(00)00039-2, 2000.

Schirrmeister, L., Grosse, G., Schnelle, M., Fuchs, M., Krbetschek, M., Ulrich, M., Kunitsky, V., Grigoriev, M., Andreev, A., Kienast, F., Meyer, H., Babiy, O., Klimova, I., Bobrov, A., Wetterich, S., and Schwamborn, G.: Late Quaternary paleoenvironmental records from the western Lena Delta, Arctic Siberia, Palaeogeogr. Palaeoclimatol. Palaeoecol., 299, 175-196, doi:10.1016/j.palaeo.2010.10.045, 2011.

Schouten, S., Hopmans, E. C., and Sinninghe Damsté, J. S.: The organic geochemistry of glycerol dialkyl glycerol tetraether lipids: A review, Organic Geochem., 54, 19-61, doi:10.1016/j.orggeochem.2012.09.006, 2013.

Schuur, E. A. G., Vogel, J. G., Crummer, K. G., Lee, H., Sickman, J. O., and Osterkamp, T. E.: The effect of permafrost thaw on old carbon release and net carbon exchange from tundra, Nature, 459, 556-559, doi:10.1038/nature08031, 2009.

Semiletov, I. and Gustafsson, Ö.: East Siberian Shelf Study Alleviates Scarcity of Observations, Eos, Transactions American Geophysical Union, 90, 145-146, doi:10.1029/2009EO170001, 2009.

Semiletov, I., Dudarev, O., Luchin, V., Charkin, A., Shin, K.-H., and Tanaka, N.: The East Siberian Sea as a transition zone between Pacific-derived waters and Arctic shelf waters, Geophys. Res. Lett., 32, L10614, doi:10.1029/2005GL022490, 2005.

Semiletov, I. P.: Aquatic Sources and Sinks of $\mathrm{CO}_{2}$ and $\mathrm{CH}_{4}$ in the Polar Regions, J. Atmos. Sci., 56, 286-306, 1999a.

Semiletov, I. P.: The failure of the coastal permafrost as an important factor in biogeochemistry of the Arctic shelf waters, Transactions of Russia Academy of Sciences [Doklady], 369, 11401143, 1999b.

Semiletov, I. P., Savelieva, N. I., Weller, G. E., Pipko, I. I., Pugach, S. P., Gukov, A. Y., and Vasilevskaya, L. N.: The Dispersion of Siberian River Flows into Coastal Waters: Meteorological, Hydrological and Hydrochemical Aspects, in: The Freshwater Budget of the Arctic Ocean, edited by: Lewis, E. L., Jones, E. P., Lemke, P., Prowse, T. D., and Wadhams, P., 323-
366, Springer Netherlands, Dordrecht, doi:10.1007/978-94-0114132-1_15, 2000.

Semiletov, I. P., Shakhova, N. E., Pipko, I. I., Pugach, S. P., Charkin, A. N., Dudarev, O. V., Kosmach, D. A., and Nishino, S.: Spacetime dynamics of carbon and environmental parameters related to carbon dioxide emissions in the Buor-Khaya Bay and adjacent part of the Laptev Sea, Biogeosciences, 10, 5977-5996, doi:10.5194/bg-10-5977-2013, 2013.

Shakhova, N. and Semiletov, I.: Methane release and coastal environment in the East Siberian Arctic shelf, J. Marine Syst., 66, 227-243, doi:10.1016/j.jmarsys.2006.06.006, 2007.

Shakhova, N., Semiletov, I., Leifer, I., Salyuk, A., Rekant, P., and Kosmach, D.: Geochemical and geophysical evidence of methane release over the East Siberian Arctic Shelf, J. Geophys. Res.-Oceans, 115, C08007, doi:10.1029/2009JC005602, 2010a.

Shakhova, N., Semiletov, I., Salyuk, A., Yusupov, V., Kosmach, D., and Gustafsson, Ö.: Extensive Methane Venting to the Atmosphere from Sediments of the East Siberian Arctic Shelf, Science, 327, 1246-1250, doi:10.1126/science.1182221, 2010 b.

Shakhova, N., Semiletov, I., Leifer, I., Sergienko, V., Salyuk, A., Kosmach, D., Chernykh, D., Stubbs, C., Nicolsky, D., Tumskoy, V., and Gustafsson, O.: Ebullition and storm-induced methane release from the East Siberian Arctic Shelf, Nature Geosci., 7, 64-70, doi:10.1038/ngeo2007, 2014.

Shakhova, N., Semiletov, I., Sergienko, V., Lobkovsky, L., Yusupov, V., Salyuk, A., Salomatin, A., Chernykh, D., Kosmach, D., Panteleev, G., Nicolsky, D., Samarkin, V., Joye, S., Charkin, A., Dudarev, O., Meluzov, A., and Gustafsson, O.: The East Siberian Arctic Shelf: towards further assessment of permafrost-related methane fluxes and role of sea ice, Philos. T. Roy. Soc. A, 373, 20140451, doi:10.1098/rsta.2014.0451, 2015.

Shakhova, N. E., Sergienko, V. I., and Semiletov, I. P.: The contribution of the East Siberian shelf to the modern methane cycle, Herald of the Russian Academy of Sciences, 79, 237-246, doi:10.1134/S101933160903006X, 2009.

Sinninghe Damsté, J. S., Rijpstra, W. I. C., Hopmans, E. C., Jung, M.-Y., Kim, J.-G., Rhee, S.-K., Stieglmeier, M., and Schleper, C.: Intact Polar and Core Glycerol Dibiphytanyl Glycerol Tetraether Lipids of Group I.1a and I.1b Thaumarchaeota in Soil, Appl. Environ. Microbiol., 78, 6866-6874, doi:10.1128/AEM.01681-12, 2012.

Sparkes, R. B., Dogrul Selver, A., Bischoff, J., Talbot, H. M., Gustafsson, Ö., Semiletov, I. P., Dudarev, O. V., and van Dongen, B. E.: GDGT distributions on the East Siberian Arctic Shelf: implications for organic carbon export, burial and degradation, Biogeosciences, 12, 3753-3768, doi:10.5194/bg-12-3753-2015, 2015.

Spencer, R. G. M., Mann, P. J., Dittmar, T., Eglinton, T. I., McIntyre, C., Holmes, R. M., Zimov, N., and Stubbins, A.: Detecting the signature of permafrost thaw in Arctic rivers, Geophys. Res. Lett., 42, 2830-2835, doi:10.1002/2015GL063498, 2015.

Spencer-Jones, C. L., Wagner, T., Dinga, B. J., Schefuß, E., Mann, P. J., Poulsen, J. R., Spencer, R. G. M., Wabakanghanzi, J. N., and Talbot, H. M.: Bacteriohopanepolyols in tropical soils and sediments from the Congo River catchment area, Organic Geochem., 89-90, 1-13, doi:10.1016/j.orggeochem.2015.09.003, 2015.

Talbot, H. M. and Farrimond, P.: Bacterial populations recorded in diverse sedimentary biohopanoid 
distributions, Organic Geochem., 38, 1212-1225, doi:10.1016/j.orggeochem.2007.04.006, 2007.

Talbot, H. M., Squier, A. H., Keely, B. J., and Farrimond, P.: Atmospheric pressure chemical ionisation reversed-phase liquid chromatography/ion trap mass spectrometry of intact bacteriohopanepolyols, Rapid Communications in Mass Spectrometry, 17, 728-737, doi:10.1002/rcm.974, 2003a.

Talbot, H. M., Summons, R., Jahnke, L., and Farrimond, P.: Characteristic fragmentation of bacteriohopanepolyols during atmospheric pressure chemical ionisation liquid chromatography/ion trap mass spectrometry, Rapid Communications in Mass Spectrometry, 17, 2788-2796, doi:10.1002/rcm.1265, 2003b.

Talbot, H. M., Watson, D. F., Pearson, E. J., and Farrimond, P.: Diverse biohopanoid compositions of non-marine sediments, Organic Geochem., 34, 1353-1371, doi:10.1016/S01466380(03)00159-1, 2003c.

Talbot, H. M., Coolen, M. J. L., and Damste, J. S. S.: An unusual 17 alpha, 21 beta(H)-bacteriohopanetetrol in Holocene sediments from Ace Lake (Antarctica), Organic Geochem., 39, 1029-1032, doi:10.1016/j.orggeochem.2008.01.008, 2008.

Talbot, H. M., Handley, L., Spencer-Jones, C. L., Dinga, B. J., Schefuß, E., Mann, P. J., Poulsen, J. R., Spencer, R. G. M., Wabakanghanzi, J. N., and Wagner, T.: Variability in aerobic methane oxidation over the past 1.2 Myrs recorded in microbial biomarker signatures from Congo fan sediments, Geochim. Cosmochim. Acta, 133, 387-401, doi:10.1016/j.gca.2014.02.035, 2014.

Taylor, K. A. and Harvey, H. R.: Bacterial hopanoids as tracers of organic carbon sources and processing across the western Arctic continental shelf, Organic Geochem., 42, 487-497, doi:10.1016/j.orggeochem.2011.03.012, 2011.

Tesi, T., Semiletov, I., Hugelius, G., Dudarev, O., Kuhry, P., and Gustafsson, Ö.: Composition and fate of terrigenous organic matter along the Arctic land-ocean continuum in East Siberia: Insights from biomarkers and carbon isotopes, Geochim. Cosmochim. Acta, 133, 235-256, doi:10.1016/j.gca.2014.02.045, 2014.

Tesi, T., Semiletov, I., Dudarev, O., Andersson, A., and Gustafsson, Ö.: Matrix association effects on hydrodynamic sorting and degradation of terrestrial organic matter during cross-shelf transport in the Laptev and East Siberian shelf seas, J. Geophys. Res.Biogeosci., 121, 731-752, doi:10.1002/2015JG003067, 2016.

van Dongen, B. E., Semiletov, I., Weijers, J. W. H., and Gustafsson, Ö.: Contrasting lipid biomarker composition of terrestrial organic matter exported from across the Eurasian Arctic by the five great Russian Arctic rivers, Global Biogeochem. Cy., 22, GB1011, doi:10.1029/2007GB002974, 2008.

van Everdingen, R.: Multi-language glossary of permafrost and related ground-ice terms, International Permafrost Association, 2005.

van Winden, J. F., Talbot, H. M., De Vleeschouwer, F., Reichart, G.-J., and Sinninghe Damsté, J. S.: Variation in methanotroph-related proxies in peat deposits from Misten Bog, Hautes-Fagnes, Belgium, Organic Geochem., 53, 73-79, doi:10.1016/j.orggeochem.2012.07.001, 2012a. van Winden, J. F., Talbot, H. M., Kip, N., Reichart, G.-J., Pol, A., McNamara, N. P., Jetten, M. S. M., den Camp, H. J. M. O., and Sinninghe Damsté, J. S.: Bacteriohopanepolyol signatures as markers for methanotrophic bacteria in peat moss, Geochim. Cosmochim. Acta, 77, 52-61, doi:10.1016/j.gca.2011.10.026, 2012b.

Vonk, J. E., Sanchez-Garcia, L., van Dongen, B. E., Alling, V., Kosmach, D., Charkin, A., Semiletov, I. P., Dudarev, O. V., Shakhova, N., Roos, P., Eglinton, T. I., Andersson, A., and Gustafsson, O.: Activation of old carbon by erosion of coastal and subsea permafrost in Arctic Siberia, Nature, 489, 137-140, doi:10.1038/nature11392, 2012.

Vonk, J. E., Tank, S. E., Bowden, W. B., Laurion, I., Vincent, W. F., Alekseychik, P., Amyot, M., Billet, M. F., Canário, J., Cory, R. M., Deshpande, B. N., Helbig, M., Jammet, M., Karlsson, J., Larouche, J., MacMillan, G., Rautio, M., Walter Anthony, K. M., and Wickland, K. P.: Reviews and syntheses: Effects of permafrost thaw on Arctic aquatic ecosystems, Biogeosciences, 12, 7129-7167, doi:10.5194/bg-12-7129-2015, 2015.

Wagner, D., Gattinger, A., Embacher, A., Pfeiffer, E.-M., Schloter, M., and Lipski, A.: Methanogenic activity and biomass in Holocene permafrost deposits of the Lena Delta, Siberian Arctic and its implication for the global methane budget, Glob. Change Biol., 13, 1089-1099, doi:10.1111/j.1365-2486.2006.01331.x, 2007.

Wagner, T., Kallweit, W., Talbot, H. M., Mollenhauer, G., Boom, A., and Zabel, M.: Microbial biomarkers support organic carbon transport from methane-rich Amazon wetlands to the shelf and deep sea fan during recent and glacial climate conditions, Organic Geochem., 67, 85-98, doi:10.1016/j.orggeochem.2013.12.003, 2014.

Welander, P. V., Hunter, R. C., Zhang, L., Sessions, A. L., Summons, R. E., and Newman, D. K.: Hopanoids Play a Role in Membrane Integrity and $\mathrm{pH}$ Homeostasis in Rhodopseudomonas palustris TIE-1, J. Bacteriol., 191, 6145-6156, doi:10.1128/JB.00460-09, 2009.

Xu, Y., Cooke, M. P., Talbot, H. M., and Simpson, M. J.: Bacteriohopanepolyol signatures of bacterial populations in Western Canadian soils, Organic Geochem., 40, 79-86, doi:10.1016/j.orggeochem.2008.09.003, 2009.

Zhang, T., Barry, R. G., Knowles, K., Heginbottom, J. A., and Brown, J.: Statistics and characteristics of permafrost and ground-ice distribution in the Northern Hemisphere, Polar Geography, 31, 47-68, doi:10.1080/10889370802175895, 2008.

Zhu, C., Talbot, H. M., Wagner, T., Pan, J. M., and Pancost, R. D.: Distribution of hopanoids along a land to sea transect: Implications for microbial ecology and the use of hopanoids in environmental studies, Limnol. Oceanogr., 56, 1850-1865, doi:10.4319/lo.2011.56.5.1850, 2011. 